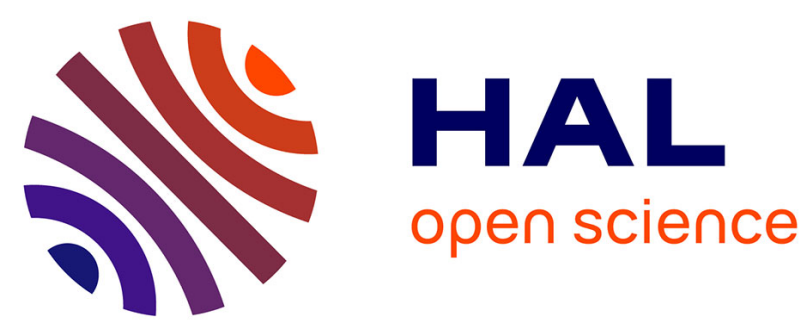

\title{
Segmentation of the Himalayan megathrust around the Gorkha earthquake (25 April 2015) in Nepal
}

Jean-Louis Mugnier, François Jouanne, Roshan Bhattarai, Joaquim Cortes-Aranda, Ananta Gajurel, Pascale Leturmy, Xavier Robert, Bishal Upreti, Riccardo Vassallo

\section{To cite this version:}

Jean-Louis Mugnier, François Jouanne, Roshan Bhattarai, Joaquim Cortes-Aranda, Ananta Gajurel, et al.. Segmentation of the Himalayan megathrust around the Gorkha earthquake (25 April 2015) in Nepal. Journal of Asian Earth Sciences, 2015, 141, Part B, pp.236 - 252. 10.1016/j.jseaes.2017.01.015 . hal-03135843

\section{HAL Id: hal-03135843 https://hal.science/hal-03135843}

Submitted on 11 Feb 2021

HAL is a multi-disciplinary open access archive for the deposit and dissemination of scientific research documents, whether they are published or not. The documents may come from teaching and research institutions in France or abroad, or from public or private research centers.
L'archive ouverte pluridisciplinaire HAL, est destinée au dépôt et à la diffusion de documents scientifiques de niveau recherche, publiés ou non, émanant des établissements d'enseignement et de recherche français ou étrangers, des laboratoires publics ou privés. 


\title{
Segmentation of the Himalayan megathrust around the Gorkha earthquake (25 April 2015) in Nepal
}

\section{For Journal of Asian Earth Sciences}

\author{
Jean-Louis Mugnier ${ }^{\text {ab }}$, François Jouanne ${ }^{\text {a }}$, Roshan Bhattarai ${ }^{\mathrm{c}}$, Joaquim Cortes- \\ Aranda $^{\text {af }}$, Ananta Gajurel ${ }^{\mathrm{c}}$, Pascale Leturmy ${ }^{\mathrm{d}}$, Xavier Robert ${ }^{\mathrm{e}}$, Bishal Upreti ${ }^{\mathrm{c}}$, Riccardo \\ Vassallo $^{\text {a }}$ \\ ${ }^{\text {a } U n i v e r s i t e ́-d e ~ S a v o i e ~ M o n t ~ B l a n c, ~ I S T e r r e, ~ F-73376 ~ L e ~ B o u r g e t ~ d u ~ L a c, ~ F r a n c e ~}$ \\ ${ }^{\mathrm{b}}$ CNRS, ISTerre, F-73376 Le Bourget du Lac, France \\ ${ }^{\mathrm{c}}$ Department of Geology, Tribhuvan University, Kathmandu, Nepal \\ ${ }^{\mathrm{d}}$ Université Cergy-Pontoise, France \\ ${ }^{\mathrm{e}}$ Université Grenoble Alpes, ISTerre, F-38041 Grenoble, France \\ ${ }^{\mathbf{f}}$ Departamento de Ciencias de la Tierra, Universidad de Concepción, Chili
}

\section{Abstract}

We put the 25 April 2015 earthquake of Nepal (Mw 7.9) into its structural geological context in order to specify the role of the segmentation of the Himalayan megathrust. The rupture is mainly located NW of Kathmandu, at a depth of 13-15 km on a flat portion of the Main Himalayan Thrust (MHT) that dips towards the N-NE by 7 to $10^{\circ}$. The northern bound of the main rupture corresponds to the transition towards a steeper crustal ramp. This ramp, which is partly coupled during the interseismic period, is only locally affected by the earthquake. The southern bound of the rupture was near the leading edge of the Lesser Himalaya antiformal duplex and near the frontal footwall ramp of the upper Nawakot duplex. The rupture has been affected by transversal structures: on the western side, the Judi lineament separates the main rupture zone from the nucleation area; on the eastern side, the Gaurishankar lineament separates the 25 April 2015 rupture from the 12 May 2015 (Mw 7.2) rupture. The origin of these lineaments is very complex: they are probably linked to pre-Himalayan faults that extend into the Indian shield beneath the MHT. These inherited faults induce transverse warping of the upper lithosphere beneath the MHT, control the location of lateral ramps of the thrust system and concentrate the hanging wall deformation at the lateral edge of the ruptures. The MHT is therefore segmented by stable barriers that define at least five patches in Central Nepal. These barriers influence the extent of the earthquake ruptures. For the last two centuries: the 1833 (Mw 7.6) earthquake was rather similar in extent to the 2015 event but its rupture propagated south-westwards from an epicentre located NE of Kathmandu; the patch south of Kathmandu was probably affected by at least three earthquakes of $\mathrm{Mw} \geq 7$ that followed the 1833 event a few days later or 33 years (1866 event, Mw 7.2) later; the 1934 
earthquake ( $\mathrm{Mw} 8.4$ ) had an epicentre $\sim 170 \mathrm{~km}$ east of Kathmandu, may have propagated as far as Kathmandu and jumped the Gaurishankar lineament.

This combined structural approach and earthquake study allows us to propose that the MHT in the central/eastern Himalaya is segmented by stable barriers that define barrier-type earthquake families. However for each individual earthquake within a family, the rupture histories could be different. Furthermore, the greatest earthquakes could have broken the barriers and affected the patches of several families. The concept of a regular recurrence of characteristic earthquakes is therefore misleading to describe the succession of Himalayan earthquakes.

\section{Key words:}

Megathrust, barriers, duplex, Himalayan earthquakes, Kathmandu, structural geology

\section{Introduction}

The Nepal earthquake of 25 April 2015 followed a serie of great earthquakes that damaged the Kathmandu basin (Chitrakar and Pandey, 1986; Pant, 2002; Mugnier et al., 2011, Bollinger et al., 2014). It is the first event simultaneously recorded by high-rate GPS (e.g. Avouac et al., 2015), teleseismic waves (e.g. Fan and Shearer, 2015), SAR imaging (e.g. Lindsey et al., 2015), strong-motion recordings (e.g. Grandin et al., 2015) and by a local seismometer network (Adhikari et al., 2015).

However, the April 2015 earthquake remains enigmatic in terms of the classical understanding of the Himalayan seismic cycle (e.g. Avouac et al., 2001) for several reasons:

(1) Great earthquakes generally initiate at the brittle/ductile transition of the MHT and propagate along ramp and flat segments of the brittle part of the crust (e.g. Avouac et al., 2001). However, the northern part of the 2015 rupture zone was located several tens of kilometres to the south of the interseismic locking line defined from geodetic data (e.g. Jouanne et al., 2016) and did not show any clear evidence of dip variations on the MHT (e.g. Avouac et al., 2015; Yagi and Okuwaki, 2015). This raises the following questions: did the 2015 earthquake initiate at the brittle transition and did it affect a ramp? 
(2) Numerous great earthquakes broke the MHT until they reached the surface (e.g. Kumar et al., 2006) whereas the 2015 earthquake was characterized by a lack of slip on the shallower (southern) part of the MHT (Galetzka et al., 2015) and did not reach the surface. The following questions are then raised: why is there no propagation further south? Is there a stable barrier (Aki, 1979) or a transient effect in the propagation dynamic?

(3) The 2015 rupture followed three earthquakes in the Kathmandu area during the last two centuries (Fig. 1): the 1934 (Dunn et al., 1939), 1866 (Oldham, 1883) and 1833 events (Bilham, 1995). Do they form a repetition of characteristic earthquakes (Schwartz et al., 1981; Schwartz and Coppersmith, 1984)?

(4) Are the ruptures of the successive earthquakes overlapped or separated by strong zones along the MHT that act as barriers when the stress level does not reach the rupture strength or as asperities when they break (Aki, 1984)?

In order to answer these questions, the role of the geological structures in the seismic cycle has to be considered. A consistency between local reductions in stress estimated from strong motion during earthquakes and those inferred from geological observation has been evidenced (Aki, 1984); this consistency supports the possibility of predicting strong motion data for earthquakes directly from the geological interpretation of the causative fault. In a thrust system, a geometric framework based on flats, ramps and related folds is classically used (e.g. Boyer and Elliott, 1982) whereas the geometry can be considered as a succession of kinematic increments (Endignoux and Mugnier, 1990). Seismic events integrate the release of elastic deformation stored during the seismic cycle and therefore furnish the minimum increment of irreversible deformation (Sibson, 1983) that affects a thrust system.

In order to link earthquakes and geological structures in the central Himalaya, we recall in this paper: (1) the geometry of the crustal-scale structures (e.g. Pearson and De Celles, 2005; Kayal, 2008; Dhital, 2015); (2) the location of the active tectonics of central Nepal (Delcaillau, 1992; Leturmy, 1997; Lavé and Avouac, 2000; Dasgupta et al., 2000); (3) the succession of historic earthquakes (e.g. Chen and Molnar, 1977; Ambraseys and Douglas, 2004; Mugnier et al., 2011) including detailed knowledge of the 2015 earthquake. A detailed comparison is performed between the 2015 earthquake and the geological structures in order to detect the effects of structures at the hanging wall or footwall of the MHT on the extent of 
great earthquakes. A structural segmentation of the MHT is evidenced and its influence on seismic hazards is discussed.

\section{Tectonics and structures of the Himalaya}

\subsection{The crustal-scale structures of the Himalaya in central Nepal}

The MHT presently displaces a stack of thrust sheets that form the Himalaya (Le Fort, 1975). The MHT reaches the surface at the front of Himalaya (e.g. Schelling and Arita, 1991) and is called the Main Frontal Thrust at this location (MFT in Figs. 1 and 3). The MHT absorbs approximately $20 \mathrm{~mm} / \mathrm{yr}$ of convergence in Nepal on the geological time scale (Lavé and Avouac, 2000; Mugnier and Huyghe, 2006).

A crustal ramp along the MHT has been deduced from balanced cross-sections (e.g. Schelling and Arita, 1991) and indirect models (Pandey et al., 1995; Lavé and Avouac, 2001; Pearson and De Celles, 2005; Robert et al., 2011). Nonetheless, the MHT is only locally imaged by geophysical data (Zhao et al., 1993; Schulte-Pelkum et al., 2005; Nabelek et al., 2009; Berthet et al., 2013, Gao et al., 2016). Duputel et al. (2016) found that the 2015 rupture occurred in a low velocity zone located between 10 and $15 \mathrm{~km}$ beneath the Kathmandu area but the image remains imprecise. The dip and depth of the 2015 rupture inferred from seismology data and the inversion of the displacement field (e.g. Galetzka et al., 2015; Zhang et al., 2015) are therefore new data that specify the geometry of the MHT. They have been incorporated in this paper into an interpretative crustal cross-section that is discussed below.

The Main Central Thrust (MCT) is undoubtedly the most studied structure in the Himalayan fold-thrust belt (see summary by Upreti, 1999); yet despite much work, no clear consensus exists in the literature on how to identify the fault. We follow Heim and Gansser (1939) in defining the Main Central Thrust as the structure that places rocks from the Greater Himalayan zone above rocks from the Lesser Himalayan zone. It has been shown (e.g. Hagen, 1969) that the MCT extends until the Mahabharat range south of Kathmandu (Fig. 2) beneath what is usually called the "Kathmandu nappe" (Rai, 1998). The MCT is passively folded by the underneath structures and depicts a regional antiform north of Kathmandu and a synform beneath Kathmandu. 
At the footwall of the MCT, the evolution of the Lesser Himalaya has been studied by structural analysis (e.g. DeCelles et al., 2001), high-temperature evolution modelling (e.g. Bollinger et al., 2006) and low-temperature thermochronology methods (e.g. Robert et al., 2011). The Lesser Himalaya is usually considered as a thrust system that follows a classical tectonic evolution (e.g. Boyer and Elliot, 1982) rather than the base of a channel flow ductile zone (Beaumont et al., 2001). Numerous décollement levels are found in the Lesser Himalaya series (Table 1 adapted from Pearson and DeCelles, 2015 and Shresta et al., 1985) and delineate at least three structural units (Fig. 2A and 3A) that are hereafter called the Robang formation, the antiformal duplex and the upper duplex.

The topmost of the present-day stacked Lesser Himalayan units is the Robang formation (Stocklin, 1980) also called Kushma formation in Central Nepal (Bordet et al., 1964; Upreti, 1999). It encompassed in an inverse thermal gradient zone (e.g. Bollinger et al., 2006). The origin of the inverted metamorphism is still largely debated (e.g. Kohn, 2016) and we follow Pearson and De Celles (2005) in defining a thrust nearly parallel to the MCT that places greenschist-grade rocks of the Lesser Himalaya above the less metamorphosed series. In the Kathmandu area, the metamorphic grade mainly decreases at the base of the Robang formation (Pearson and De Celles, 2005). Previously, the Robang formation was considered as the very upper part of the upper Nawakot unit (Stocklin, 1980), but detrital zircon U-Pb dating, with ages close to $1860 \mathrm{Ma}$ (De Celles et al., 2000), indicates that the Robang is actually the stratigraphically lowest Lesser Himalayan unit exposed in central Nepal (Table 1) and is the lateral equivalent of the Ramgarh thrust sheet in the western Himalaya defined by Heim and Gansser (1939). Therefore, the Robang formation is considered in the following (Fig. 3) as a structural unit at the hanging wall of the Ramgarh thrust (RT). This unit is frequently drawn as a thin continuous layer (e.g. De Celles et al., 2001) but its geometry is surely more complex at the detailed scale (e.g. Schresta et al., 1985). In the cross-section, we follow the simplification provided by De Celles et al. (2001).

An antiformal stack duplex (Fig. 2C adapted from Pearson and De Celles, 2005; Mukul, 2010) is formed of sediments from the Lower Nawakot unit (i.e. the lower part of the Lesser Himalayan formations). Its roof thrust is located at the base of the Dandagaon formation whereas its floor thrust is at the top of the Robang formation. The stratigraphic thickness of the antiformal duplex is nearly $6 \mathrm{~km}$ (Upreti, 1999) and three horses crop out in 
central Nepal (LD1 to LD3 in Fig. 2A) whereas two others (LD4 and LD5) are inferred at depth in order to develop the regional anticline defined by Pecher (1978).

The Upper Nawakot unit (upper part of the Lesser Himalayan formations) forms a thin duplex mainly developed beneath the southern and western part of the Kathmandu nappe (Fig. 2A). The geometry of the trailing and lateral edges of this duplex is complex due to a succession of cross-cutting thrust events that leads to the juxtaposition of pieces from different formations (Stocklin, 1980). The roof thrust is the RT whereas the floor thrust is located at the base of the Dandagaon formation; this roof thrust delineates the southern limit of the Lesser Himalaya domain, usually called the Main Boundary Thrust (MBT) (e.g. Gansser, 1964). A branching off between the MBT and MCT (white dots in Fig. 2A from Dhital, 2015) suggests that the upper Nawakot unit is not continuous beneath the Kathmandu nappe. RamgarhThe Siwalik belt of Himalaya is made up of syn-orogenic Siwaliks sediments and is located above the most external part of the MHT. The MHT is usually emergent at the MFT in central Nepal (e.g. Schelling et al., 1991) but could tip onto growing anticlines (Fig. 4A; e.g. Mugnier et al., 1992). Locally, a frontal growing structure folds the emergent frontal thrust (Fig. 4B). The frontal structure transports older structures that are the Main Dun Thrust (MDT from Hérail and Mascle, 1980) and the Internal Décollement Thrust (ID from Mugnier et al., 1999) located close to the Main Boundary Thrust. South of Kathmandu, thin sheets of Lesser Himalaya sediments (Hérail and Mascle, 1980) are incorporated into the hanging wall of the ID (Fig. 4B) and are similar in age to the Dandagaon formation (1.5-1.7 Ga from Takigami et al., 2002 and Pearson and De Celles, 2005). The ID and MBT therefore branch off a décollement at the floor of the upper Nawakot duplex.

Based on line length balancing of the units between the MFT and ID (Lavé and Avouac, 2000), the footwall cut-off of the Upper Nawakot series is located more than $15 \mathrm{~km}$ to the north of the ID. Furthermore, the footwall ramp of the upper duplex is not farther than $40 \mathrm{~km}$ to the north of the ID, as a fission track exhumation age (Robert, 2009) suggests that the Sub-Himalayan tectonics post-date $2 \mathrm{Ma}$ and as the quaternary shortening rate was close to $20 \mathrm{~mm} / \mathrm{yr}$ (Mugnier et al., 2006).

The timing of the thrust system evolution is still in discussion but becoming more and more precisely known (e.g. Kohn, 2016). A crude restoration (Fig. 3B and C) has been performed. It is surely not an exact representation of the specificities of the tectonic evolution of this part of the Himalayan thrust belt but is rather an illustration of how the Himalayan 
thrusts superposed different stratigraphic levels experiencing different metamorphic conditions. It has been performed assuming a $20 \mathrm{~mm} / \mathrm{yr}$ shortening since $10 \mathrm{Ma}$, a value estimated from the migration of the foreland basin (Mugnier et al., 2006) and therefore independent from any local interpretation of the kinematics and thermal evolution of the Himalayan thrust belt. Nonetheless, the inferred evolution agrees with the cooling story beneath $120^{\circ} \mathrm{C}$ (from apatite fission tracks) of the Palung granites (dot $P$ south of Kathmandu in Fig. 3A) that indicates transport above a gently dipping segment of the MHT since more than $6 \mathrm{Ma}$ and suggests a strong underthrusting component (Robert et al., 2011). It also agrees with the thermal story inferred for the Langtang area north of the present-day MCT (dot $L$ in Fig. 3A) that indicates a cooling beneath $120^{\circ} \mathrm{C}$ as late as $1.5 \mathrm{Ma}$ related to a recent transport above a ramp segment of the MHT (Robert et al., 2011). The cooling beneath $350^{\circ} \mathrm{C}$ of this area occurred before $\sim 10 \mathrm{Ma}$ (Bollinger et al., 2006) due to exhumation above a ramp at the trailing edge of the Proterozoic craton (De Celles et al., 2002). The cooling of the Palung granite began before $17 \mathrm{Ma}$ due to its exhumation during the MCT activity (Bollinger et al., 2006). The forward propagating thrust sequence used for this sketch is a simplification and the antiformal duplex could begin to develop before the Upper Nawakot duplex, i.e. before 5 Ma (Pearson and De Celles, 2005). Furthermore, the Upper Nawakot unit could be affected by early thrusts at the footwall of the MCT, as proposed by Celerier et al. (2009) in Kumaun (in yellow in Fig. 3b).

In summary, the geometry of the footwall of the MHT is characterized by the southern frontal ramp, a flat detachment beneath the Siwalik and Lesser Himalayan zones, a crustal ramp cutting through the upper crust of the Indian plate, and a lower flat that extends far to the north beneath the Tibetan Plateau. In addition to this classically described geometry (e.g. Schelling and Arita, 1991), some minor ramps probably affect the flat segments. The hanging wall of the MHT is formed of a succession of different lithologies that are the crystalline sheet of the High Himalaya, a duplex of Lesser Himalaya sediment, locally metamorphic rocks beneath the Kathmandu nappe, an imbricate of the upper part of the Lesser Himalaya rocks and Siwaliks sediments.

\subsection{The structures transverse to the thrust belt of the Himalaya}


The dip, location and size of the MHT crustal ramp varies laterally along strike on the scale of the Himalaya (Pandey et al., 1999). The crustal ramp all along the Himalayan belt is probably formed of a succession of ramps connected by structures transverse to the

221 Himalaya; the location of some of these structures has already been inferred from mechanical modelling (Berger et al., 2004), thermo-kinematic modelling (Robert et al., 2011), interseismic deformation (Jouanne et al., 2016) and the cartographic pattern of the foreland and Himalayan structures (Shresta et al., 1985; Mugnier et al., 1999).

The Himalayan foreland shows a regular increase in the thickness of the synorogenic Himalayan sediment towards the belt (Pascoe, 1964; Lyon-Caen and Molnar, 1985) but the foreland basement is also affected laterally by pre-Himalayan basins, basement highs and pre-Himalayan faults (Raiverman et al., 1994).

The most active basement fault during the Himalayan orogeny is the Kishanganj fault located in eastern India (Rao et al., 2015). It is a vertical dextral strike-slip fault that crosses the whole crust of the foreland and extends through the Himalaya of Sikkim and even through the Tibetan plateau (Mukul, 2010) where it offsets the South Tibetan detachment (STD) system. It slips during earthquakes as large as Mw 6.9 (Sikkim earthquake 18/09/2011) which affect the crust beneath the MHT (Paul et al., 2015). It is the crustal scale lateral ramp of the Shillong crustal pop-up (Clark and Bilham, 2008) that affects the foreland.

To the west of the Shillong structure, the deformation of the Indian shield is weak and the pre-Himalayan faults are poorly reactivated during the Himalayan collision although locally affected by microseisms (e.g. Dasgupta et al., 2000).

In the central Himalaya, one of the most prominent features of the foreland is the Gandak depression (Fig. 1) linked to a Proterozoic basin located beneath a thick Himalayan foredeep (e.g. Raiverman et al., 1994). In central Nepal, a quaternary basin (Narayani dun, $\mathrm{Na}$ in Fig. 1) develops above the tectonic wedge of the Siwalik belt west of longitude $84^{\circ} \mathrm{E}$ and reaches more than $30 \mathrm{~km}$ wide to the north of the Gandak depression. Numerical models (Mugnier et al., 1999) suggest that such development is favoured by an increase in the depth of the basal décollement and is consistent with a lateral increase in the flexure of the Indian crust in this area. This lateral warping of the crust beneath the MHT is modelled by Berger et al. (2004) as a vertical offset that affects the MHT. 
Transverse lineaments are inferred in the Himalaya belt (e.g. Kayal, 2008). They are evidenced by geomorphologic features (e.g. Harvey et al., 2015), faults revealed by aerial or satellite image analysis that cut through previous structures (e.g. Dasgupta et al., 1987), earthquake epicentre clustering and strike-slip focal mechanisms (e.g. Dasgupta et al., 2000). In the central Himalaya, the most prominent features (Kayal, 2008) are the Judi (or "Trisuli transfer fault" from Mugnier et al., 2011) and Gaurishankar (or "Chautara lineament" from Verma, 1985) lineaments that trend SSW-NNE and cross the entire Himalayan belt west and east of Kathmandu respectively (Fig. 1 and 2A).

Several sinistral strike slip focal mechanisms (Dasgupta et al., 2000) and the 29/10/1988 Mw 5.2 (Larson, 1999) and 24/03/1974 Mw 5.8 (Molnar, 1990) medium thrust earthquakes were recorded along the Gaurishankar lineament. The Judi lineament coincides with a slight $\mathrm{N}-\mathrm{S}$ offset of the cluster of microseisms (Rajaure et al., 2013).

There is very little clear evidence of present-day surface motion along the Gaurishankar and Judi lineaments. The Judi lineament nonetheless cartographically offsets the trace of the MCT and the Siwalik structures. Another fault close and parallel to the Judi lineament offsets the antiformal stack duplex (Shresta et al., 1985). The Gaurishankar lineament also offset the MCT and MBT south of Kathmandu.

These lineaments may have a long-lasting tectonic story. The Judi lineament is located above the warping of the Indian crust inferred from the widening of the accretionary wedge and the deepening of the Gandak depression (Mugnier et al., 2011). The Gaurishankar lineament coincides with the pierce point of the branch line, as defined by Diegel (1986), between the MBT and MCT at the front of the Kathmandu Nappe. It also coincides with the pierce point of the branch line between the roof and floor thrust of the LD2 horse (Fig. 2A); this coincidence suggests that the lineament could be located above a lateral edge of the upper duplex of the Lesser Himalaya (Fig. 2B).

In summary, the origin of the lineaments is very complex: they are probably linked to pre-Himalayan faults that presently extend in the Indian shield beneath the MHT and control the development of the Himalayan thrust system. These inherited faults induce transverse warping of the flexed crust beneath the Himalayan belt and control the location of lateral ramps that affect both the footwall and hanging wall of the thrust system. The late active 
faulting and earthquake clustering could be small kinematics discontinuities above irregularities in the MHT plane but are localized above long-lasting lineament zones.

\subsection{Active faults and present-day deformation of the central Himalaya}

The active tectonics of the Himalaya mainly occur in the frontal belt. Trenching has been performed through the MFT and records earthquakes (e.g. Bollinger et al., 2014). Some of the events seen in the trenches can be correlated to historic earthquakes and prove the extent of their ruptures as far as the front, like for the 1934 earthquake that ruptured the MFT (Sapkota et al., 2013). In other portions of the frontal belt, the active frontal ramp tips into growing anticlines (Fig. 4A) where tilted terraces are not breached by any ruptures. An active out-of-sequence thrust reactivation of the MBT and MDT is clearly evidenced in western Nepal (Mugnier et al., 1994; 2005) but they are probably secondary in central Nepal (Elliott et al., 2016).

Active faults have been observed around Kathmandu (Fig. 2). Faults located close to the Mahabharat Range forming the southern boundary of the Kathmandu basin (MF in Fig. 2) show an uplift of the southern block with respect to the northern one (Saijo et al., 1995). The Jhiku Khola fault (JF in Fig. 2) is a right-lateral strike-slip fault with a thrust component that reactivates the roof thrust of the antiformal duplex (Kumahara et al., 2016). In all cases, their long-term motions remain very small (a few tens of metres during thousands of years).

Active faulting is also inferred along the MCT from exhumation modelling or geomorphologic studies (Wobus et al., 2006). However other thermochronologic studies point to only a small degree of thrust reactivation along the MCT (Robert et al., 2011). Furthermore, the only field observations of active faulting observed in the MCT are located in the western Himalaya and are related to strike-slip or normal faulting (Nakata, 1989; Silver et al., 2015).

Some of the normal faults affecting the Tibetan plateau (Fig. 1) extend to the High Himalaya (Armijo et al., 1986). All these active faults are seismogenic, but they are located 
above the ductile MHT and therefore do not interact with the seismic cycle of the brittle MHT or only poorly so (Avouac et al., 2001).

During interseismic periods, geodetic surveys show that the ductile part of the MHT continuously absorbs $\sim 19 \mathrm{~mm} / \mathrm{yr}$ of convergence in the central Himalaya (e.g. Ader et al., 2012), whereas its external part is locked. In the Kathmandu area, Jouanne et al. (2016) determine that coupling decreases towards the north from $\sim 0.8$ to 0.5 along the ramp; the coupling still decreases to the north along the lower flat and reaches values smaller than 0.2 more than $10 \mathrm{~km}$ north of the crustal ramp. Therefore, the free slip is only localized along the lower flat north of the Himalaya whereas the upper flat of the MHT is totally locked during the interseismic period.

Due to the high coupling, no post-seismic creeping is affecting the MHT south of the 2015 earthquake whereas significant post-seismic deformation is occurring to the north of the 2015 rupture (Jouanne et al., 2015), in a zone of moderate coupling and that was poorly affected by the aftershock sequence (Adhikari et al., 2015). This type of post-seismic creeping was already observed to the north of the 2005 Kashmir earthquake (Jouanne et al., 2011).

In summary, the active thrusts branching off the frontal part of the MHT absorb nearly $19 \mathrm{~mm} / \mathrm{yr}$ of convergence in Nepal on the scale of several seismic cycles but only slip during great earthquakes (Bollinger et al., 2014). The other numerous active faults observed in the Himalayan wedge are of second order.

\section{Great earthquakes in the Kathmandu Valley and Nepal}

Kathmandu, which is the largest city in the Himalaya of Nepal, is a centre of civilization with more or less continuous historical chronicles since the thirteenth century (Chitrakar and Pandey, 1986). At least 10 major earthquakes (Pant, 2002; Mugnier et al., 2011; Bollinger et al., 2014) feature in the historical records of the Kathmandu valley.

The quality of archives has greatly improved since the eighteenth century and can be used to estimate the magnitude of the great Himalayan earthquakes (Ambraseys and Douglas, 2004). Therefore, only these earthquakes are discussed below. For this period, the biggest 
earthquakes in the Kathmandu basin occurred in 1934 (Mw 8.4), 2015 (Mw 7.9), 1833 (Mw 7.6) and 1866 (Mw 7.2) (See Fig. 1 and 5A for locations).

\subsection{The earthquakes of the $19^{\text {th }}$ and $20^{\text {th }}$ centuries}

The main 1833 earthquake on 26 August was preceded by two foreshocks that drove people outdoors in alarm thereby reducing loss of life. The main shock reached an intensity of IX MM (Modified Mercalli) in the Kathmandu area and locally up to an intensity of X MM in the southern part of the basin (Bilham, 1995). The main event was followed by two events with an intensity of VIII-IX MM in Kathmandu on 4 and 18 September (Bilham, 1995), the epicentres of which were possibly located south of Kathmandu (Mugnier et al., 2011).

The main 1833 earthquake was recorded throughout the region from Tibet to the Ganga plain; it strongly affected the Tibetan regions located north of Kathmandu. It has been subsequently proposed that the epicentre was located beneath the Ganga plain (Oldham, 1883), in western Nepal (Seeber and Armbruster, 1981), and to the north/northeast (Bilham, 1995), northeast (Thapa, 1997) and east (Ambraseys and Douglas, 2004; Szeliga et al., 2010) of Kathmandu. Based on the orientation of the fractures and dykes that developed during the 1833 events, Mugnier et al. (2013) suggested an epicentre located to the northeast of Kathmandu (Fig. 5A).

The extent of the 1833 rupture is poorly constrained and estimates of its magnitude vary from Mw 7.7 (Bilham, 1995) to 7.2 (Szeliga et al., 2010). However we consider that the most robust estimate is Mw 7.6, as proposed by Ambraseys and Douglas (2004). As the extent of the zone of MMI VIII damage for the 1833 event nearly fits with damage from the 2015 event, it is suggested that the 1833 rupture coincided with a very large portion of the April 2015 event (Martin et al., 2015).

Two aftershocks close to Mw 7 followed the 1833 earthquake on 4 and 18 October 1833 (Chitrakar and Pandey, 1986) and could have been located south of Kathmandu (Mugnier et al., 2011).

The 1866 earthquake occurred on 23 May near Kathmandu (Oldham, 1883; Khattri, 1987). The magnitude and epicentre location are poorly constrained due to a lack of observations north of Kathmandu. Nonetheless, on the basis of the intensity versus attenuation 
relationships for the Indian subcontinent and Himalayan region, Szeliga et al. (2010) suggest an epicentre location south of Kathmandu with a magnitude of $\mathrm{Mw}$ 7.2.

The 1934 earthquake strongly shook eastern Nepal and the Bihar plain. Ambraseys and Douglas (2004) proposed that zone VII of the MKS modified scale (Fig.1) extended more than $250 \mathrm{~km}$, from Sikkim to the west of Kathmandu, and was affected by destruction greater than VII on the MKS modified scale. Rana (1935) and Dunn et al. (1939) reported damage with a MM Intensity of X in the Kathmandu basin. The 1934 earthquake killed $20 \%$ of the population, destroyed $20 \%$ of all buildings and damaged $40 \%$ of them in the Kathmandu Valley (Pandey and Molnar, 1988). Amplification effects occurred in the Kathmandu area (Pandey and Molnar, 1988) and in the slump belt of the Ganga plain (Dunn et al., 1939, Fig.1). The epicentre location, $\sim 170 \mathrm{~km}$ east of Kathmandu, is based on three tele-seismic stations (Chen and Molnar, 1977)

Recent trenching demonstrates that a $\sim 3 \mathrm{~m}$ surface rupture affected the MFT during the 1934 earthquake (Sapkota et al., 2013). From this morphologic evidence, the 1934 event ruptured the entire locked zone of the MHT (Bollinger et al., 2014) and reached the surface at least between $85^{\circ} 50^{\prime} \mathrm{E}$ and $87^{\circ} 30^{\prime} \mathrm{E}$. There is less evidence of surface ruptures towards the west. Nonetheless, Delcaillau (1986) observed an undated surface rupture $20 \mathrm{~km}$ further west. Furthermore, the zones of MMI >X in the slump belt (Dun et al., 1939) and zones of subsidence in the Terai plain (Bilham et al., 1998) extending westwards as far as $85^{\circ} \mathrm{E}$, suggest a 1934 rupture that affected the frontal belt up to that point. The absence of a clear surface rupture could be linked to the superposition of an active fault propagation-fold beneath a presently emerging inactive fault (Fig. 4B), as suggested by the tilting of a recent continuous terrace above the MFT (Plate 8a in Lavé and Avouac, 2000) and by active deformation observed north of the slump belt along the Bagmati River (Goswami, 2012).

The length, width and instrumental magnitude of the source for the 1934 Bihar-Nepal earthquake were estimated at 220, $120 \mathrm{~km}$ and Mw 8.4 respectively (Molnar and Qidong, 1984), whereas the macroseismic magnitude is only Mw 8.1 (Ambraseys and Douglas, 2004). A similar slight macro seismic effect was also noticed for the 1905 Himalayan earthquake (Molnar, 1987; Hough and Bilham, 2008) and for the 2015 earthquake (Martin et al., 2015).

\subsection{The 2015 earthquake}


from Martin et al., 2015), was of greater extent than the rupture of the Kashmir 2005 event that caused nearly 100,000 fatalities (Kaneda et al., 2008). Furthermore, no surface slip was recorded during the 2015 earthquake (e.g. Angster et al., 2015; Kumahara et al., 2016).

401

402

403

404

405

406

407

408

409

410

411

412

413

The nodal plane strikes $\mathrm{N} 113^{\circ} \mathrm{E}$ and dips $7^{\circ}$ to the north from the GCMT (Ekström et al., 2012), and the finite-fault model from the U.S. Geological Survey National Earthquake Information Center (NEIC) provides a similar result (strike $\mathrm{N} 115^{\circ}$ and dip $10^{\circ}$ ).

The main rupture occurred to the southeast of the epicentre. The slip was less than 2 $\mathrm{m}$ until $\sim 25 \mathrm{~km}$ southeast of the epicentre (Fig. 5A); there, the slip increases and the main rupture occurred along a 13-15 km deep patch extending approximately $80 \mathrm{~km}$ along strike and $25 \mathrm{~km}$ along dip (Grandin et al., 2015) where the slip is larger than $4 \mathrm{~m}$ and reaches $7 \mathrm{~m}$.

A three-stage rupture process is suggested from the back projection of the low frequency teleseismic P waves (Fan and Shearer, 2015) (Fig. 5B): First, a down dip rupture at the nucleation area for the first $20 \mathrm{~s}$, then an along-strike rupture which released more than $2 / 3$ of the radiated energy along the main slip patch from 20 to $40 \mathrm{~s}$, and a last stage with up dip rupture northeast of Kathmandu. During the second stage, the main slip patch broke unilaterally towards the east in the mode III of rupture (e.g. Erdogan, 2000), with a steady and rather low velocity of 3.1-3.3 km/s (Avouac et al., 2015) and was impeded southwards in the slip direction (Galetzka et al., 2015).

A great earthquake (Mw 7.2, 12 May) occurred 17 days later east of the rupture of the 25 April earthquake; this aftershock was presumably the result of stress loading induced by the main shock and therefore indicates an asperity on the MHT (Yagi and Okuwaki, 2015). The asperity interpretation is reinforced by the close occurrence (Fig. 6 and Table 2) of the 24 
March 1974 earthquake (Mw 5.8) (Molnar, 1990) and of the 26 April 2015 aftershock (Mw 6.7) (Adhikari et al., 2015).

The aftershock sequence was formed of more than 550 earthquakes with a local magnitude greater than 4.0 (Fig. 6 adapted from Adhikari et al., 2015). This sequence was spilt into two stages: the first one before the 12 May 2015 earthquakes during which most of the events are located between the Judi and Gaurhisankar lineaments and the second one after 12 May where numerous events occurred east of the Gaurhisankar lineaments, although numerous events still occurred between the Judi and Gaurhisankar lineaments.

\section{Discussion:}

\subsection{Relationship between the structures and the transversal extent of the 2015 Gorkha} earthquake.

An interpretative cross-section through the 2015 rupture has been performed (Fig. 7). This crustal cross-section is interpretative and surely not fully balanced in Figure 3 because the geometry of the Kathmandu nappe is not cylindrical. It is rather similar to the cross-section provided by Pearson and De Celles (2005), but incorporates the following specific features:

(1) The dip and depth of the upper flat of the MHT beneath Kathmandu is estimated from the results obtained by mechanical modelling (Avouac et al., 2015) of the field deformation during the 2015 earthquake and which suggests a regular dip for the main rupture patch equal to the dip of the gentle auxiliary plane. The dip of the upper flat of the MHT (7 to $10^{\circ}$ ) is therefore slightly greater than previously inferred (e.g. Lavé and Avouac, 2001).

(2) The ramp/flat transition is punctuated by high-frequency seismic sources during the April 2015 rupture (Elliott et al., 2016); it is related to the nearly linear, in map view, northern border of the main cluster of aftershocks (Fig. 6) as well as to the seismic cluster recorded during the 1995-2003 interseismic period and relocated by Rajaure et al. (2013) (yellow surface in cross-section view in Fig. 7). As the middle of the non-relocated seismic cluster was previously inferred to be close to the middle of the ramp (Pandey et al., 1995), we consider in this work a ramp that is slightly further north than previously inferred by Lavé and Avouac (2000) or Pearson and De Celles (2005). The northern tip of the 2015 rupture is 
located on the ramp/flat transition or on the very upper part of the ramp (see discussion below).

(3) Seismic reflection lines provide an accurate depth of $\sim 5 \mathrm{~km}$ for the basal décollement beneath the Siwalik belt (Bashyal, 1998) and suggests a rather simple geometric continuity between this décollement and the gently dipping patch of the MHT that ruptured during the 2015 earthquake. This MHT geometry is different from the very flat one proposed by Duputel et al. (2016) but is still located in the low velocity zone evidenced by Duputel et al. (2016).

(4) A small footwall ramp along the MHT is nonetheless inferred beneath the synform axis of the Kathmandu nappe to allow a restoration of the external horses of the upper duplex of the Lesser Himalaya (see paragraph 2.1). The stratigraphic thickness of the external horses is only a few hundred metres and the height of the footwall ramp is expected to be the same.

(5) The structural thickness of the antiformal duplex is 16 to $18 \mathrm{~km}$ above the upper flat of the MHT where it is formed by three superposed horses and suggests a stratigraphic thickness close to $6 \mathrm{~km}$. This purely geometric estimate of the thickness of the lower Nawakot units coincides with the estimate from stratigraphic field studies (Upreti, 1999).

(6) A dip of $20^{\circ}$ for the ramp is inferred from the inverse thermo-kinematic modelling of Robert et al. (2011). A progressive transition between the upper flat and the ramp is nonetheless suggested and an intermediate segment is tentatively indicated with a dip of $14^{\circ}$ in Figure 7, based on the most probable change in dip angle found by Elliott et al. (2016).

(7) The footwall height of the crustal ramp is assumed to be similar to the stratigraphic thickness of the horses and the base of the crustal ramp is therefore at a depth of nearly 21 $\mathrm{km}$.

The 2015 rupture tipped southwards beneath the complex zone of the Kathmandu nappe (Fig. 7), like in oceanic subduction zones where earthquake ruptures frequently terminate before the outer accretionary wedge (Byrne et al., 1988). The increase in effective normal stress associated with decreased fluid pressure is known to be a possible cause of such a termination (Ujiie and Kimura, 2014) and fluids are also play a major role in fault zone mechanics within a continental domain (e.g. Faulkner et al., 2010). In particular, a strong correlation between metamorphism and frictional strength is usually evidenced because 
porosity loss and cementation occur during metamorphism inducing changes in fluid distribution and strain-hardening (Lockner, 1995).

Duputel et al. (2016) suggest that frequency-dependent rupture process for the 2015 April earthquake would related to fluids. As the hanging wall of the MHT beneath the Kathmandu nappe is formed of thrust slices of various lithologies and very variable metamorphism - from no metamorphosed series to greenschist or higher metamorphosed series (greater than $9 \mathrm{kbar}$ and $580^{\circ} \mathrm{C}$ from Martin et al., 2010) - the part of the MHT located beneath the Kathmandu nappe could locally have less porosity and greater frictional strength than the part of the MHT located beneath the antiformal duplex formed by weak metamorphic rocks of the Lesser Himalaya. Furthermore, we cannot exclude that the 2015 rupture tipped onto the footwall ramp of the upper duplex. Conversely, there is no correlation between the southern edge of the rupture and the variations in altitude, and there are no reasons to infer that the edge of the rupture is linked to a decrease in the stress level along the MHT.

In summary, the southern tip of the 2015 earthquake could be related to the effects of fluid pressure variations linked to metamorphic and porosity variations in the hanging wall slices as well as the geometric irregularity associated with a footwall ramp. In both cases, a stable strength barrier (Aki, 1979) could be therefore considered south of Kathmandu.

The northern boundary of the 2015 earthquake can be defined from several lines of understanding:

Comparison between several previous studies (e.g. Lavé and Avouac, 2001; Robert et al., 2011; Mugnier et al., 2013)and 2015 rupture location suggest that the the northern boundary of the 2015 earthquake is located close to the geometric singularity defined by a ramp/flat transition.

Modelling of the coseismic slip assuming a flat MHT (Grandin et al., 2015) indicates a northern boundary of the rupture that fits with the northern boundary of the aftershock seismicity (from Adhikari et al., 2015). This result validates the assumption that the MHT was flat.

Direct modelling of the MHT geometry based on surface displacement (Elliott et al., 2016) suggests that the northern tip of the 2015 rupture is located on an upper flat/ramp transition or on the very upper part of the ramp. Regardless, in this last case, the large slip 
zone is exclusively located on the flat; Fan and Shearer (2015) suggest that the slip occurred on the ramp mainly during the first and last stages of the rupture.

The segment of the MHT located to the north of the 2015 rupture seems to be characterized by temperatures less than $400^{\circ} \mathrm{C}$ (Robert et al., 2011) and therefore is in a brittle regime with a very high seismic coupling during the interseismic period (e.g. Ader et al., 2012). Nonetheless, most of the seismotectonic models of the great Himalayan earthquakes postulate that the earthquakes would nucleate at the brittle ductile transition where coupling is very low (e.g. Avouac et al., 2001). Such low coupling (smaller than 0.2) is found on the lower flat more than $10 \mathrm{~km}$ to the north of the base of the crustal ramp (Jouanne et al., 2016) or even more than $50 \mathrm{~km}$ (Elliott, 2016). Therefore, a segment of the MHT located to the north of the 2015 rupture stores elastic energy that could possibly be released during another great earthquake nucleated further to the north. This interpretation explains that the epicentres of very large (greater than the Gorkha 2015 event) historical earthquakes were located to the north of the crustal ramp (Mugnier et al., 2013).

The example of the 2015 earthquake therefore suggests at least three possible origins for the locations of the edges of a rupture in the Himalaya (Fig. 8): 1) hanging wall cut-offs of a ramp and/or the branching of transported faults induce variations in the lithology and possibly in the fluid pressures; 2) footwall cut-offs form geometric singularities along the trajectory of the active fault or 3 ) thermal conditions induce a brittle/ductile transition.

\subsection{Relationship between the structures and lateral extent of the 2015 Gorkha Earthquake.}

The origin of the structures transverse to the Himalayan belt is very complex, and their role in the segmentation of the MHT is possibly related to numerous causes: a simple lateral ramp causes a variation in the lithology at the hanging wall in the external part (Fig. 9, cross-section a-a') and an offset of the detachment in the inner part (Fig. 9, cross-section bb'). The long-lasting evolution of the pre-Himalayan faults keeps the causes more complex: a reactivation of a pre-existing strike-slip as a wrench fault in the basement, like the Kishanganj fault in eastern India (Rao et al., 2015), offsets the detachment (Fig. 9, cross-section c-c'); small steps or transverse warping linked to a reactivation of a pre-existing fault could also affect the footwall of the MHT (Fig. 9, cross-section d-d'); lateral variations in the pre- 
Himalayan sedimentary pile, like in the Dehra Dun area (Rajendra Prasad et al., 2011), could control the location of a lateral ramp, inducing a footwall step in the inner (northern) part (Fig. 9, cross-section e-e') and a hanging wall structure in the outer part (Fig. 9, cross-section $\left.f-f^{\prime}\right)$. Finally, the deformation at the tips of the successive seismic events occurring on each side of a lineament would have induced a superposition of numerous small phases of deformation, but the final deformation resulting from this superposition is almost nul and the total displacement is also null in this zone that we consider as the lineament zone.

The term lineament therefore has frequently an imprecise structural meaning but we feel that the above definition is suitable given the poor knowledge of the origin of the segmentation in the Himalaya.

Variations in the geometry of the MHT crustal ramp have been evidenced on the scale of the Himalaya (see the above discussion in section 2.2). In central Nepal, the structures at the hanging wall of the MHT are not cylindrical: The height of the antiformal stack and the base of the nappe declines beneath Kathmandu (Rai, 1988). The geological structures of the hanging wall are therefore not regular around the 2015 rupture and it is suggested that the lineaments play a role based on the following comparisons evidenced in Figures 5 and 6:

1) On the western side, stages 1 and 2 of the propagation of the 25 April 2015 rupture are separated by the Judi lineament (Fig. 5B from Fan and Shearer, 2015). The western limit of the major stage (stage 2) of the 25 April earthquake therefore correlates to this geological structure.

2) The cluster of micro-seismic events during the interseismic period is less regularly aligned at its intersection with the Judi lineament (Rajaure et al., 2013).

3) The eastern side of the aftershock sequence that occurred between the 25 April and 12 May earthquakes was delineated by the Gaurishankar Lineament (Fig. 6).

4) The 12 May 2015 earthquake and its own related aftershock sequence occurred on the eastern side of the Gaurishankar lineament (Adhikari et al., 2015). 
5) The greater than $\mathrm{Mw} \geq 6$ earthquakes of the aftershock sequences ruptured at a deeper level to the east of the Gaurishankar lineament (Adhikari et al., 2015). This deepening is also suggested from a crustal image (Pandey and Kumar, personal communication).

In summary, a portion of the MHT is bounded by structural features all around the major stage of the 2015 rupture: to the north, by a footwall crustal ramp beneath the axis of the antiformal duplex; to the west, by a footwall structure that also affects the hanging wall of the MHT (Judi lineament); to the east, by the Gaurishankar lineament, whereas the southern limit is presumably linked to structural complexities at the leading edge of the hanging wall antiformal duplex and/or to the footwall ramp of the upper duplex.

\subsection{Seismotectonic scenario for the Kathmandu area}

Apart from their scientific interest, the understanding of the 2015 earthquake reflects a major threat for communities as it is only a matter of time until the next great earthquake happens in this densely populated area. As a result, at least two questions are raised:

- Will the frontal part of the MHT release the strain at the southern tip of the 2015 event?

- Will a great earthquake affecting the brittle MHT (like the Mw 7.9 2015 earthquake) release all the elastic strain inherited from the preceding interseismic period and only that strain (Bollinger et al., 2014)? Or will it also release an elastic energy that would affect the whole Tibet-India convergence and that has remained unreleased during one or more of the earlier earthquakes (Mugnier et al., 2013)?

A simple slip budget assuming characteristic earthquakes with a different recurrence time for each patch could be proposed: the rupture of the upper flat patch would have a recurrence interval of $\sim 180$ years (from the lapse between the 1833 and 2015 earthquakes) whereas the eastern and western patches would have a recurrence interval of $\sim 800$ years, as proposed by Bollinger et al. (2014 and 2016). The southern patch would also break in order to complete the slip budget of the 2015 event. Nonetheless, a detail analysis shows several complexities compared to such a simple scenario:

1) The historical earthquakes in the Himalaya are still poorly known before the $19^{\text {th }}$ century, and the regularity of their return time is still debated. Mugnier et al. (2013) found an 
596

597

598

599

600

601

602

603

604

605

606

607

608

609

610

611

612

613

614

615

616

617

618

619

620

621

622

623

624

625

626

627

irregular cycle that would vary between 834 and 250 years for earthquakes as great as or greater than the 1934 earthquake, whereas Bollinger et al. (2014) suggested a regular cycle, with return times that would range between $750 \pm 140$ and $870 \pm 350$ years, i.e. between 610 and 1250 years. This uncertainty is therefore so great that a regular recurrence of characteristic earthquakes cannot be proven.

2) A future rupture of the southern patch is inferred to release the strain at the southern tip of the 2015 event through a shallow earthquake located between the barriers formed by the southern tip of the 2015 earthquake, the Himalayan front, the Gaurishankar lineament and the Judi lineament. The application of the Kanamori (1983) equation to this $45 \times 80 \mathrm{~km}^{2}$ area would predict a Mw 7.7 earthquake if the slip is the same as the 2015 earthquake. However, the case of the 1833 earthquake indicates a sequence formed of several earthquakes of $\mathrm{Mw} \geq$ 7 and which occurred 45 and 59 days after the 1833 main shock or 33 years later in 1866 south of Kathmandu (Szeliga et al., 2010). This suggests a future clustering of events rather than a unique event. In any case, the delay before the next earthquake is difficult to assess.

\section{3) The 1934 earthquake could have simultaneously ruptured several patches. In} the scenario of characteristic earthquakes, the Gaurishankar lineament would form the western boundary of the 1934 earthquake and its rupture would stop more than $40 \mathrm{~km}$ from Kathmandu. Nonetheless, a comparison of the intensity of the destruction (Grunthal, 1998) for the 1833, 1934 and 2015 earthquakes indicates the quake in the Kathmandu area was smaller in 1833 than in 1934, of the same order in 1934 and 2015 or possibly greater in 1934 (Martin et al., 2015). The much more extensive destruction to dwellings induced by the 1934 event in Kathmandu (20\% of the buildings in Kathmandu were destroyed in 1934; Rana, 1935, less than $1 \%$ in 2015) could reflect the effects of a proximal rupture source during the 1934 earthquake, in addition to improvements in building practices. Furthermore, Molnar and Quidong (1984) proposed a lateral extent of $220 \mathrm{~km}$ for the 1934 earthquake, which includes a portion of the MHT west of the Gaurishankar lineament. Therefore, in our opinion, the Gaurishankar barrier could have been broken during the 1934 earthquake and the above defined barriers do not delineate all the great earthquakes.

4) The strain release cycle along the upper flat patch of the MHT remains unclear. The slip during the 2015 earthquake is greater than $4 \mathrm{~m}$ and locally reaches $7 \mathrm{~m}$ (Grandin et al., 2015), a value equivalent to 200-350 years of Himalayan convergence. As the 2015 and 1833 events were separated by 182 years, the strain released in 2015 is slightly greater than the strain 
stored. If the 1934 earthquake also affected this patch, the released strain between 1833 and 2015 is much greater than the locally stored strain and a background storage of energy beneath Tibet has to be involved (Fedl and Bilham, 2006).

\subsection{Towards a "barrier type" framework for interpreting the succession of historic earthquakes in central Himalaya}

The concept of a "barrier-type" earthquake family was defined by Aki (1984) and is associated with a highly heterogeneous fault plane containing weak barriers distributed between stronger barriers; the location of the latter remain stable during numerous seismic cycle. The stable barriers may be unbroken in repeated earthquakes, and the weaker ones may break in different patterns. The slip could vary depending on the location of the initial asperity that is broken and on the distribution over the fault plane of barriers left unbroken after each earthquake. This type of earthquake family therefore shares the same fault plane but could display a great range in variations in terms of the amount of slip and rupture histories.

This "barrier-type" earthquake family model differs from the characteristic earthquake model proposed by Schwartz et al. (1981) as it suggests that earthquakes could have a characteristic fault length but not a characteristic amount of slip nor a regular recurrence. We suggest that the concept of "barrier-type" earthquake family could be useful in the Himalaya for the following reasons.

During the 2015 earthquake, the macroseismic effects were rather small (Martin et al., 2015) and are consistent with a model where numerous weak barriers slow down the propagation along the ruptured patch (Fan and Schearer, 2015).

There was a gap with low to negligible slip between the April and May 2015 earthquakes (Zhang et al., 2015). This zone, located beneath the Gaurishankar lineament, probably acted as a barrier in the most recent earthquakes.

The 1833 earthquake could have a rupture zone (Mugnier et al., 2013) analogous to stages " 2 and 3" of the 2015 earthquake defined by Fan and Shearer (2015). Therefore the two earthquakes could be limited by the same structural features. However the rupture story of the two events are clearly different: the 2015 rupture initiated at the western side of the rupture zone and ended at the north-eastern side close to the epicentre of the 1833 event whereas the 1833 rupture probably propagated south-westwards from this epicentre. We therefore consider 
658

659

660

661

662

663

664

665

666

667

668

669

670

671

672

673

674

675

676

677

678

679

680

681

682

683

684

685

686

687

that the 1833 and 2015 earthquakes are members of a same "barrier-type earthquake family" as defined by Aki (1984).

From a combined structural approach and earthquake study, we propose that the MHT in the central Himalaya is affected by stable barriers. Five barrier-type earthquake families (Fig. 10) may have produced the earthquakes that affected the Kathmandu area: (1) the upper flat patch was affected by the 1833 and 2015 earthquakes and possibly the 1934 earthquake; (2) the eastern patch was affected by the 1934 event; (3) the southern patch was affected by the 1866 earthquake; (4) a western patch did not rupture during the last two centuries and possibly since the 1255 event and 5) the northern patch is characterized by intermediate seismic coupling.

Stable barriers have been broken during other earthquakes in the Himalaya and several patches ruptured simultaneously, like in the inferred 1934 case:

The Dehra Dun earthquake in 1905 (Hough and Bilham, 2008) also illustrates a rupture that was split into two parts by a lateral ramp linked to a change in the Lesser Himalaya thickness series (Rajendra Prasad et al., 2011). The main rupture occurred to the west of this structure (Wallace et al., 2005) but a patch located to the east was also affected by the rupture (Hough and Bilham, 2008). This structural segmentation of the 1905 event is probably one of the causes for slight macro seismic effects associated with this Himalayan earthquake (Molnar, 1987).

In western Nepal, Ambraseys and Jackson (2003) suggest that the 1505 earthquake affected the MHT north of the Bhari Gad fault system (e.g. Silver et al., 2015) whereas Yule et al. (2006) found that this earthquake reached the front. Therefore, at least two structural patches of the MHT, separated by a clearly expressed active fault system in the hanging wall, ruptured during this great earthquake.

In the Kathmandu area, the 1255 earthquake is a major event (Pant, 2002), although his location is presently strongly debated (Pierce et al., 2016). By taking into account the synthesis performed by Mugnier et al. (2013) and the recent trenches performed by Chamlagain et al. (2016), we consider that this earthquake ruptured the MHT both south and west of Kathmandu. 
Strong broken barriers would leave space for very large events. In this last case, the released energy would be linked to the elastic deformation located beneath Tibet; it would be greater than the one locally stored during the last preceding interseismic period and could potentially give rise to giant events (Feldl and Bilham, 2006).

However the breaking of the barriers would extend the duration of the released energy during the propagation of the rupture, as occurred during the 2011 Tohoku Japan earthquake (e.g. Maercklin et al. (2012). The scope of giant events (Fedl and Bilham, 2006) is therefore still open but would require more studies to specify the dates and extent of the historic earthquakes, in order to estimate the associated slip as well as to model the mechanics of the rupture along a MHT segmented by a succession of weak and strong barriers.

\section{Conclusion}

The comparison between the geological structures, the 2015 seismic rupture history and the succession of earthquakes during the last two centuries suggests that:

(1) The main stage of the April 2015 rupture, which released most of the radiated energy, occurred along a flat segment of the MHT whereas the initial and final stages of the rupture mainly occurred along the crustal ramp located further north.

(2) The rupture of the April 2015 earthquake was bounded on all sides by geological structures: the footwall crustal ramp beneath the axis of the antiformal duplex (northern limit), the lineaments that originated in the footwall of the MHT but also affects the hanging wall (Judi lineament on the western limit; Gaurishankar lineament on the eastern limit), whereas the southern limit is linked to lithologic variations close to the leading edge of the antiformal duplex at the hanging wall of the MHT or to the footwall ramp of the upper Nawakot duplex.

(3) The 1833 earthquake involved nearly the same limits as the 2015 event. Nonetheless, the propagations of the ruptures during the 1833 and 2015 earthquakes were different as their epicentres were located to the NE and the NW of Kathmandu, respectively. We suggest that a patch of the MHT, delimited by geologic structures, defines a "barrier-type earthquake family" north of Kathmandu. The earthquake members of this family share the same fault plane limited by stable barriers, but the slip could vary depending on the distribution over the 
fault plane of the barriers that were left unbroken after each great earthquake and the location of the initial asperity where the rupture initiates. Therefore, a repetition of characteristic earthquakes associated with this patch is not suggested.

(4) The stable barriers around the April 2015 earthquake suggest the definition of four other patches along the MHT in the central/eastern Himalaya: a patch south of Kathmandu and affected by the 1866 earthquake; a western patch locked since at least 1505 and possibly since 1255; a northern patch mildly coupled beneath the High Himalaya and a patch located beneath eastern Nepal and affected by the 1934 event.

(5) The extent of the 1934 earthquake remains a question of prime importance. If the rupture zone of the 1934 earthquake was completely distinct from those of the April 2015 event, the latter would presumably have released all the interseismic strain stored since 1833, and only that strain. If the 1934 event also affected the same patch, then the 2015 earthquake released more strain energy than the elastic strain linked to the deformation of this zone during the preceding interseismic period and therefore released a regional elastic strain produced by the Tibet-India convergence that had remained unreleased through earlier earthquakes. This question is not still definitively resolved, but in our opinion, the stable barriers defined around the April 2015 rupture might have been broken, or not, depending the events, leading to scenarios based on a relatively random sequence of events.

(6) The dual behaviour of the stable barriers - to break or to not break - has to be taken into account in the discussion of giant Himalayan events. Broken barriers would leave space for very large events but the presence of rather strong barriers would affect the propagation of the rupture and extend the duration of the released radiated energy.

On the western side of the Kathmandu patch, there is still no reliable information due to the fact that no great earthquakes have occurred over the last 500 years. The size of the western Nepal seismic gap is large and the stored elastic energy that has remained unreleased since the 1255 or the 1505 earthquakes is huge. Therefore, the seismic hazard in the central Nepal area remains very high. A combined analysis of the structural geology, geomorphology and geophysics in the vicinity of the transverse lineaments appears to be a useful tool to better assess the seismic hazard in the central Himalaya seismic gap. 


\section{Acknowledgements}

University of Savoie Mont Blanc, Institut National de l'Univers and Institut des

750

751

752

753

754

755

756

757

758

759

760

761

762

763

764

765

766

767

768

769

770

771

772

773

774

775

776

777

\section{References}

Ader, T., Avouac, J.P., Liu-Zeng, J., Lyon-Caen, H., Bollinger, L., Galetzka, J., Genrich, J., Thomas, M., Chanard, K., Sapkota, S.N., Rajaure, S., Shrestha, P., Ding, L., Flouzat, M., 2012. Convergence rate across the Nepal Himalaya and interseismic coupling on the Main Himalayan Thrust: Implications for seismic hazard. Journal Geophysical Research Solid Earth 117, 1-16. doi:10.1029/2011JB009071

Adhikari, L.B., Gautam, U.P., Koirala, B.P., Bhattarai, M., Kandel, T., Gupta, R.M., Timsina, C., Maharjan, N., Maharjan, K., Dahal, T., Hoste-Colomer, R., Cano, Y., Dandine, M., Guilhem, A., Merrer, S., Roudil, P., Bollinger, L., 2015. The aftershock sequence of the 2015 April 25 Gorkha-Nepal earthquake. Geophysical Journal International 203, 2119-2124.

Aki, K., 1979. Characterization of barriers on an earthquake fault. Journal Geophysical Research 84, 6140. doi:10.1029/JB084iB11p06140

Aki, K., 1984. Asperities, barriers, characteristic earthquakes and strong motion prediction. Journal Geophysical Research 89, 5867-5872.

Ambraseys, N., Jackson, D., 2003. A note on early earthquakes in northern India and southern Tibet. Science 84, 571-582.

Ambraseys, N., Douglas, J., 2004. Magnitude calibration of north Indian earthquakes. Geophysical Journal International 158, 1-42.

Angster S., Fielding E., Wesnousky S., Pierce I., Chamlagain D., Gautam D., Upreti B., Kumahara Y., Nakata T., 2015. Field reconnaissance after the 25 April 2015 M 7.8 Gorkha earthquake. Seism Res Lett. doi:10.1785/0220150135

Armijo, R., Tapponnier, P., Mercier, J.L., Han, T.L., 1986. Quaternary extension in southern Tibet: Field observations and tectonic implications. Journal Geophysical Research 91, 13803-13872. 
Avouac, J.P., Bollinger, L., Lavé, J., Cattin, R., Flouzat, M., 2001. Le cycle sismique en Himalaya, Comptes Rendus de l'Academie de Sciences - Serie IIa: Sciences de la Terre et des Planètes. doi:10.1016/S1251-8050(01)01573-7

Avouac J.P., A.J., Meng, L., Wei, S., Wang, W., Ampuero, J.P., 2015. Lower edge of locked Main Himalayan Thrust unzipped by the 2015 Gorkha earthquake. Nature and Geosciences. ISSN 1752-0894.

Bashyal, R.P., 1998. Petroleum exploration in Nepal. Journal Nepal Geological Society $18,19-24$.

Beaumont, C., Jamieson, R.A., Nguyen, M.H., Lee, B., 2001. Himalayan tectonics explained by extrusion of a low-viscosity crustal channel coupled to focused surface denudation. Nature 414, 738-742.

Berger, A., Jouanne, F., Hassani, R., Mugnier, J.L., 2004. Modelling the spatial distribution of present-day deformation in Nepal: How cylindrical is the Main Himalayan Thrust in Nepal? Geophysical Journal International 156, 94-114. doi:10.1111/j.1365246X.2004.02038.X

Berthet, T., Hetényi, G., Cattin, R., Sapkota, S.N., Champollion, C., Kandel, T., Doerflinger, E., Drukpa, D., Lechmann, S., Bonnin, M., 2013. Lateral uniformity of India Plate strength over central and eastern Nepal. Geophysical Journal International 195, 14811493. doi:10.1093/gji/ggt357

Bilham, R., 1995. Location and magnitude of the 1833 Nepal earthquake and its relation to the rupture zones of contiguous great Himalayan earthquakes. Current Science 69, $101-127$.

Bilham, R., Blume, R., Bendick, R., Gaur, V.K., 1998. Geodetic constraints on the translation and deformation of India: Implications for future great Himalayan earthquakes. Current Science 74, 213-229.

Bollinger, L., P. Henry, and J. P. Avouac (2006), Mountain building in the Nepal Himalaya: Thermal and kinematic model, Earth Planet. Sci. Lett., 244, 58-71, doi:10.1016/j.epsl.2006.01.045.

Bollinger, L., Sapkota, S.N., Tapponnier, P., Klinger, Y., Rizza, M., der Woerd, J., Tiwari, D.R., Pandey, R., Bitri, A., de Berc, S., 2014. Estimating the return times of great Himalayan earthquakes in eastern Nepal: Evidence from the Patu and Bardibas strands of the Main Frontal Thrust. Journal Geophysical Research Solid Earth 119, 7123-7163. doi:10.1002/2014JB010970; 
Bollinger L., Tapponnier, P., Sapkota, S., Klinger, Y., 2016. Slip deficit in central Nepal: omen for a repeat of the 1344 AD earthquake? Earth, Planets and Space, 68, DOI 10.1186/s40623-016-0389-1.

Bordet, P., Krummenacher, D., Mouterde, R., Rémy, J.M., 1964. Sur la stratigraphie des séries affeurant dans la vallée de la Kali Gandaki (Népal central). Comptes rendus des séances de l'Académie des Sciences Paris, Série D 259, 414-416.

Boyer, S.E., Elliot, D., 1982. Thrust Systems. American Association Petroleum Geology Bulletin 66, 1196-1230.

Byrne, D.E., Davis, D.M., Sykes, L.R., 1988. Loci and maximum size of thrust earthquakes and the mechanics of the shallow region of subduction zones. Tectonics 7,833 . doi:10.1029/TC007i004p00833

Celerier, J., Harrison, T.M., Webb, A.A.G., Yin, A., 2009. The Kumaun and Garwhal Lesser Himalaya, India: part 1. Structure and stratigraphy. Geol. Soc. Am. Bull. 121, 12621280.

Chamlagain, D., Wesnousky, S., Kumahara, Y., Pierce, I., Karki, A., Gautam D., 2016. Geological observations on history and future of large earthquakes along the Himalayan Frontal Fault relative to the April 25, 2015 M7.8 Gorkha earthquake near Kathmandu, Nepal. Journal of Nepal Geological Society, 52, p. 53.

Chen W., Molnar P., 1977. Seismic moments of major earthquakes and the average rate of slip in central Asia. Journal of Geophysical Research 82, 2945-2969.

Chitrakar, G.R., Pandey, M.R., 1986. Historical earthquakes of Nepal. Bulletin Geological Society of Nepal 4, 7-8.

Clark, M.K., Bilham, R., 2008. Miocene rise of the Shillong Plateau and the beginning of the end for the Eastern Himalaya, Earth planet. Sci. Lett., 269(3), doi:10.1016/j.eps1.2008.01.045.

Dasgupta, S., Mukhopadhyay, M., Nandy, D.R., 1987. Active transverse features in the central portion of the Himalaya. Tectonophysics 136, 255-264. doi:10.1016/00401951(87)90028-X.

Dasgupta, S., Pande P., Ganguly D. Gupta H., 2000. Seismotectonic atlas of India and its environs. Geological Survey of India (ed.), Special Publication Series 59;

DeCelles, P.G., Gehrels, G.E., Quade, J., LaReau, B., and Spurlin, M., 2000, Tectonic implications of $\mathrm{U}-\mathrm{Pb}$ zircon ages of the Himalayan orogenic belt in Nepal: Science, v. 288, p. 497-499. 
De Celles, P.G., Robison, D.M., Quade, J., Ojha, T.P., Garzione, C.N., Copeland, P., Upreti, B.N., 2001. Stratigraphy, structure and tectonic evolution of the Himalayan fold-thrust belt in Western Nepal. Tectonics 20, 487.

De Celles, P.G., Robinson, D., and Zandt, G., 2002, Implication of shortening in the Himalayan fold-thrust belt for uplift of the Tibetan plateau. Tectonics, v. 21, p. 1062, 1087.

Delcaillau, B., 1986. Dynamique et evolution morphostructurale du piémont frontal de 1'Himalaya: les Siwaliks du Népal oriental. Revue géologie Dynamique géographie Physique 27, 319-337.

Delcaillau, B., 1992. Les Siwalik de l'Himalaya du Népal oriental: fonctionnement et évolution d'un piémont. Mémoires et document de Géographie. Edition du CNRS 205 p.

Dhital, M., 2015. Geology of the Nepal Himalaya: Regional Perspective of the Classic Collided Orogen. Springer. ISBN 978-3-319-02495-0. 498 p.

Diegel F., 1986. Topological constraints on imbricate thrust networks, example from the Mountain City Windows Tennesseee, U.S.A., J. Struc. Geol., 8, 269-279.

Dunn, J., Auden, J., Roy, S., 1939. The Bihar-Nepal Earthquake of 1934. Mem. Geological Society India 73. Survey of India, Calcutta 391 pp.

Duputel, Z., Vergne,J., Rivera L., Wittlinger, G., Farra, V., György H., 2016. The 2015 Gorkha earthquake: A large event illuminating the Main Himalayan Thrust fault; GRL doi: 10.1002/2016GL068083.

Ekström, G., Nettles, M., Dziewoński, A.M., 2012. The global CMT project 20042010: Centroid-moment tensors for 13,017 earthquakes. Physic. Earth Planetary Interior 200201, 1-9. doi:10.1016/j.pepi.2012.04.002

Elliott, J., Jolivet, R., Gonzalez, P., Avouac, J.P., Hollingsworth, J., Searle, M.P., Stevens, V.L., 2016. Himalayan megathrust geometry and relation to topography revealed by the Gorkha earthquake, Nature Geosciences, DOI: 10.1038/NGEO2623.

Endignoux, L., Mugnier, J.L., 1990. The use of a forward kinematic model in the construction of balanced cross sections. Tectonics 9, 1249-1262. doi:10.1029/TC009i005p01249

Erdogan E., 2000, Fracture Mechanics, International Journal of Solids and Structures, 27, pp. $171-183$

Fan, W., Shearer, P.M., 2015. Detailed rupture imaging of the 25 April 2015 Nepal earthquake using teleseismic $\mathrm{P}$ waves. Geophysical Research Letters doi:10.1002/2015GL064587 
Faulkner, D.R., Jackson, C.A.L., Lunn, R.J., Schlische, R.W., Shipton, Z.K., Wibberley, C. A. J., Withjack, M.O., 2010. A review of recent developments concerning the structure, mechanics and fluid flow properties of fault zones. Journal Structural Geology 32, 1557-1575. doi:10.1016/j.jsg.2010.06.009

Feldl, N., Bilham, R., 2006. Great Himalayan earthquakes and the Tibetan plateau. Nature 444, 165-170. doi:10.1038/nature05199

Galetzka, J., Melgar, D., Genrich, J.F., Geng, J., Owen, S., Lindsey, E.O., Xu, X., Bock, Y., Avouac, J.-P., Adhikari, L.B., Upreti, B.N., Pratt-Sitaula, B., Bhattarai, T.N., Sitaula, B.P., Moore, A., Hudnut, K.W., Szeliga, W., Normandeau, J., Fend, M., Flouzat, M., Bollinger, L., Shrestha, P., Koirala, B., Gautam, U., Bhatterai, M., Gupta, R., Kandel, T., Timsina, C., Sapkota, S.N., Rajaure, S., Maharjan, N., 2015. Slip pulse and resonance of Kathmandu basin during the $2015 \mathrm{Mw} 7.8$ Gorkha earthquake, Nepal imaged with space geodesy. Science, 349, 1091-1095. doi:10.1126/science.aac6383

Gao, R., Lu, Z., Klemperer, S.,Wang, H., Dong, S., Li, W., Li, H., 2016. Crustal-scale duplexing beneath the Yarlung Zangbo suture in the western Himalaya. Nature and Geoscience, DOI: 10.1038/NGEO2730

Gansser, A., 1964, Geology of the Himalayas: London, John Wiley and Sons Ltd., 289 p.

Goswami, P.K., 2012. Geomorphic evidences of active faulting in the northwestern Ganga Plain, India: implications for the impact of basement structures. Geosciences Journal 16, 289-299. doi:10.1007/s12303-012-0030-7

Grandin, R., Vallée, M., Satriano, C., Lacassin, R., Klinger, Y., Simoes, M., Bollinger, L., 2015. Rupture process of the $\mathrm{Mw}=7.92015$ Gorkha earthquake (Nepal): insights into Himalayan megathrust segmentation. Geophysical Research Letters n/a-n/a. doi:10.1002/2015GL066044

Grunthal, G., 1998. The European macro-seismic scale, EMS-98, Cahier du Centre Européen de Géodynamique et de Séismologie, 15, 101 p.

Hagen, T., 1969. Report on the geological survey of Nepal. Volume 1: preliminary reconnaissance. Denkschiiften der Schweizerischen Naturforschenden Gesellschaft. Band LXXXVI/1, $185 \mathrm{p}$.

Harvey, J., Burbank, D., Bookhagen, B., 2015. Along-strike changes in Himalayan thrust geometry: Topographic and tectonic discontinuities in western Nepal. Lithosphere 7, 511-518. 
Heim, A., Gansser, A., 1939. Central Himalaya Geological Observations of Swiss Expedition, 1936. Memoires de la Societe Helvetique des Sciences naturelles, 73. 246 p.

Hérail, G., Mascle, G., 1980. Les Siwalik du Népal central: structures et géomorphologie d'un piémont en cours de déformation. Bulletin Association Géographique Française 431, 259-267.

Hough, S.E., Bilham, R., 2008. Site response of the Ganges basin inferred from reevaluated macroseismic observations from the 1897 Shillong, 1905 Kangra, and 1934 Nepal earthquakes. Journal Earth System and Science 117, 773-782. doi:10.1007/s12040-008-00680

Jouanne, F., Latif, M., Majid, A., Kausar, A., Pecher, A., Mugnier, J.L., 2011. Current shortening across the Himalayas: quantification of interseismic deformation in Nepal and first results of postseismic deformation in Pakistan after the 8th October earthquake. Journal Geophysical Research 116, B05202, 22 PP., doi:10.1029/2010JB007893.

Jouanne, F., Gajurel, A., Mugnier, J.L., Bhattarai, R.R., Cotte, N., Upadhyaya, B.R., Pecher, A., Sapkota, S.N., Grandin, R., 2015. The 25 April Gorka earthquake: Pre and post deformations from GPS measurements, in: Proceedings of the $30^{\text {th }}$ Himalayan Karakhoram Tibet workshop, Dehra Dun.

Jouanne, F., Mugnier, J-L, Sapkota, S., Bascou, P., Pecher, A., 2016. Estimation of coupling along the Main Himalaya Thrust in Central Himalaya. Journal of Asian Earth Sciences.

Kanamori, H., 1983. Magnitude scale and quantification of earthquakes. Tectonophysics 93, 185-199. doi:10.1016/0040-1951(83)90273-1

Kaneda, H., Nakata, T., Tsutsumi, H., Kondo, H., Sugito, N., Awata, Y., Akhtar, S.S., Majid, A., Khattak, W., Awan, A. a., Yeats, R.S., Hussain, A., Ashraf, M., Wesnousky, S.G., Kausar, A.B., 2008. Surface rupture of the 2005 Kashmir, Pakistan, earthquake and its active tectonic implications, Bulletin of the Seismological Society of America. doi:10.1785/0120070073

Kayal, J.R., 2008. Microearthquake seismology and seismotectonics of South Asia. doi:10.1007/978-1-4020-8180-4

Khattri, K.N., 1987. Great earthquakes, seismicity gaps and potential for earthquake disaster along the Himalaya plate boundary. Tectonophysics 138, 79-92. doi:10.1016/00401951(87)90067-9

Kohn, M., 2016. Himalayan Metamorphism and Its Tectonic Implications. Annual Review of Earth and Planetary Sciences 42, 381-419. 
Kumahara, Y., Chamlagain, D., Upreti, B., 2016. Geomorphic features of active faults around the Kathmandu Valley, Nepal, and no evidence of surface rupture associated with the 2015 Gorkha earthquake along the faults. Earth, Planets and Space 68:53DOI 10.1186/s40623-016-0429-x.

Kumar, S., Wesnousky, S.G., Rockwell, T.K., Briggs, R.W., Thakur, V.C., Jayangondaperumal, R., 2006. Paleoseismic evidence of great surface rupture earthquakes along the Indian Himalaya. Journal Geophysical Research Solid Earth 111, 1-19. doi:10.1029/2004JB003309.

Larson, E., 1999. Global centroid moment tensor catalog. http://www.globalcmt.org/ CMTsearch.html.

Lavé, J., Avouac, J.P., 2000. Active folding of fluvial terraces across the Siwaliks Hills, Himalayas of central Nepal. Journal Geophysical Research 105, 5735. doi:10.1029/1999JB900292

Lavé, J., Avouac, J.P., 2001. Fluvial incision and tectonic uplift across the Himalayas of central Nepal. Journal Geophysical Research 106, 26561. doi:10.1029/2001JB000359

Le Fort, P., 1975. Himalayas: the collided range. Present knowledge of the continental arc. American Journal Science 275, 1-44.

Leturmy, P., 1987. Sédiments et reliefs du front des systèmes chevauchants: modèlisations et exemples du front Andin et des Siwaliks (Himalaya) à l'Holocène. PhD Université de Grenoble, 236 p.

Lindsey, E.O., Natsuaki, R., Xu, X., Shimada, M., Hashimoto, M., Melgar, D., Sandwell, D.T., 2015. Line-of-sight displacement from ALOS-2 interferometry: Mw 7.8 Gorkha Earthquake and Mw 7.3 aftershock. Geophysical Research Letters 42, 6655-6661. doi:10.1002/2015GL065385.

Lockner, D., 1995. Rock failure, in: AGU Reference Shelf (Ed.), Rock Physics and Phase Relations. Ahrens ed., pp. 127-147.

Lyon-Caen, H., and Molnar, P., 1985. Gravity anomalies, flexure of the Indian plate, and the structure, support and evolution of the Himalaya and Ganga basin. Tectonics, 4, 513538.

Maercklin N., Festa, G., Colombelli S., Zollo A., 2012. Twin ruptures grew to build up the giant 2011 Tohoku Japan earthquake. Scientific Reports, 2: 709.DOI: 10.1038/srep00709.

Martin, A.J., Ganguly, J., De Celles, P.G., 2010. Metamorphism of greater and lesser Himalayan rocks exposed in the Modi Khola valley, central Nepal. Contribution to Mineralogy and Petrology 159, 203-223. doi:10.1007/s00410-009-0424-3 
Martin, S.S., Hough, S.E., Hung, C., 2015. Ground motions from the 2015 Mw 7.8 Gorkha, Nepal, earthquake constrained by a detailed assessment of macroseismic data. Seismological Research Letters 86, 1524-1532. doi:10.1785/0220150138

Molnar, P., Qidong, D., 1984. Faulting associated with large earthquakes and the average rate of deformation in central and eastern Asia. Journal Geophysical Research 89, 6203-6227. doi:10.1029/JB089iB07p06203

Molnar, P., 1987. The distribution of intensity associated with the 1905 Kangra earthquake and bounds on the extent of the rupture zone. Journal Geological Society of India 29, 221-229.

Molnar, P., 1990. A review of the seismicity and the rates of active underthrusting and deformation at the Himalaya. Journal Himalayan Geology 1, 131-154.

Mugnier, J.L., Mascle, G., Faucher, T., 1992. La structure des Siwaliks de l'Ouest Népal: un prisme d'accrétion intracontinental. Bulletin Société Géologique France 163, 585595.

Mugnier, J.L., Huyghe, P., Chalaron, E., Mascle, G., 1994. Recent movements along the Main Boundary Thrust of the Himalayas: Normal faulting in an over-critical thrust wedge? Tectonophysics 238, 199-215. doi:10.1016/0040-1951(94)90056-6

Mugnier, J.L., Leturmy, P., Huyghe, P., Chalaron, E., 1999. The Siwaliks of western Nepal II. Mechanics of the thrust wedge. Journal Asian Earth Science 17, 643-657. doi:10.1016/S1367-9120(99)00039-5

Mugnier, J.L., Huyghe, P., 2006. Ganges basin geometry records a pre-15 Ma isostatic rebound of Himalaya. Geology 34, 445-448. doi:10.1130/G22089.1

Mugnier, J.L., Huyghe, P., Gajurel, A., Upreti, B., Jouanne, F., 2011. Seismites in the Kathmandu basin and seismic hazard. Tectonophysics 509, 33-49. doi:doi:10.1016/j.tecto.2011.05.012

Mugnier, J.L., Gajurel, a., Huyghe, P., Jayangondaperumal, R., Jouanne, F., Upreti, B., 2013. Structural interpretation of the great earthquakes of the last millennium in the central Himalaya. Earth Science Review 127, 30-47. doi:10.1016/j.earscirev.2013.09.003

Mukul, M., 2010. First-order kinematics of wedge-scale active Himalayan deformation: Insights from Darjiling-Sikkim-Tibet (DaSiT) wedge. Journal of Asian Earth Sciences, 39(6), 645-657

Nábělek, J., Hetényi, G., Vergne, J., Sapkota, S., Kafle, B., Jiang, M., Su, H., Chen, J., Huang, B.-S., the Hi-Climb Team, 2009. Underplating in the Himalaya-Tibet collision zone 
revealed by the Hi-CLIMB Experiment. Science. 325, 1371-1374. doi:10.1126/science.1167719

Nakata, T., 1989. Active faults of the Himalayas of India and Nepal: Geological Society of America Special Paper 232, 243-264.

Oldham, T., 1883. A catalogue of Indian earthquakes from the earliest time to the end of 1869 AD. Mem. Geological Survey of India 1, 163-215.

Pandey, M., Molnar, P., 1988. The distribution of intensity of the Bihar-Nepal earthquake of 15 January 1934 and bounds on the extent of the rupture zone. Journal Geological Society of Nepal 5, 22-44.

Pandey, M.R., Tandukar, R.P., Avouac, J.P., Lavé, J., Massot, J.P., 1995. Evidence for recent interseismic strain accumulation on a mid-crustal ramp in the Central Himalaya of Nepal. Geophysical Research Letters 22, 751-758.

Pandey, M.R., Tandukar, R.P., Avouac, J.P., Vergne, J., Héritier, T., 1999. Characteristics of seismicity of Nepal and their seismotectonic implications. Journal Asian Earth Sciences 17, 703-712.

Pant, M.R., 2002. A step toward a historical seismicity of Nepal. Adarsa 2, 29-69.

Pascoe, E., 1964, A manual of geology of India and Burma: Delhi, Government of India, $2130 \mathrm{p}$.

Paul H., Mitra, S., Bhattacharya, S.N., and Suresh, G., 2015, Active transverse faulting within underthrust Indian crust beneath the Sikkim Himalaya Geophys. J. Int., 201, 10701081 ;

Pearson, O.N., De Celles, P.G., 2005. Structural geology and regional tectonic significance of the Ramgarh thrust, Himalayan fold-thrust belt of Nepal. Tectonics 24, 1-26. doi:10.1029/2003TC001617

Pecher, A., 1978. Déformation et métamorphisme associé à une zone de cisaillement: exemple du grand chevauchement central Himalayen (MCT). These d'état, Grenoble University, $354 \mathrm{p}$.

Pierce, I., Wesnousky, S. (2016). On a flawed conclusion that the 1255 A.D. earthquake ruptured $800 \mathrm{~km}$ of the Himalayan Frontal Thrust east of Kathmandu. Geophysical Research Letter 43, 9026-9029

Rai, S., 1998. Les nappes de Katmandou et du Gosainkund, Himalaya du Nepal central: étude cartographique, structurale, métamorphique, géochimique et radiochronologique. PhD. University Joseph-Fourier - Grenoble I, French. https://tel.archivesouvertes.fr/tel-00640663 
Raiverman, V., Chugh, M., Srivastava, A., Prasad, D., Das, S., 1994. Cenozoic tectonic of frontal fold belt of the Himalaya and Indo-Gangetic foredeep with pointers toward hydrocarbon prospects, in: Seminar on Petroliferous Basins of India, 2nd, Proceedings. pp. $25-54$

Rajaure, S., Sapkota, S., Adhikari, L., Koirala, B., Bhattarai, M., Tiwari, D., Gautam, U.P., Shrestha, P., Maske, S., Avouac, J.-P., Bollinger, L., 2013. Double difference relocation of local earthquakes in the Nepal Himalaya. Journal Nepal Geological Society 46, 133-142.

Rajendra Prasad B., Klemperer S. L., Rao V., Tewari H.C., Khare P., 2011, Crustal structure beneath the Sub-Himalayan fold-thrust belt, Kangra recess, northwest India, from seismic reflection profiling: Implications for Late Paleoproterozoic orogenesis and modern earthquake hazard, Earth and Planetary Science Letters 308, 218-228.

Rana, B.S., 1935. Nepal Ko Maha Bhukampa (1990 Sala) Nepal's Great Earthquake.

Rao, N.P., Tiwari, V.M., Kumar, M.R. et al., 2015. The M w 6.9 Sikkim-Nepal earthquake of September 2011: a perspective for wrench faulting in the Himalayan thrust zone Nat Hazards 77: 355. doi:10.1007/s11069-015-1588-y

Robert, X., 2009. Séquence d'activité des failles et dynamique du prisme himalayen: apports de la thermochronologie et de la modélisation numérique. PhD University JosephFourier - Grenoble I,. Français. <tel-00352596>

Robert, X., Van Der Beek, P., Braun, J., Perry, C., Mugnier, J.L., 2011. Control of detachment geometry on lateral variations in exhumation rates in the Himalaya: Insights from low-temperature thermochronology and numerical modeling. Journal Geophysical Research Solid Earth 116, 1-22. doi:10.1029/2010JB007893

Saijo, K., Kimora, K., Dongol, G., Komatsubara, T., Yagi, H., 1995. Active faults in south western Kathmandu basin, Central Nepal. Journal Nepal Geological Society 11, 217224.

Sapkota, S.N., Bollinger, L., Klinger, Y., Tapponnier, P., Gaudemer, Y., Tiwari, D., 2013. Primary surface ruptures of the great Himalayan earthquakes in 1934 and 1255. Nature 6, 152. doi:10.1038/ngeo1669

Schelling, D., Arita, K., 1991. Thrust tectonics, crustal shortening, and the structure of the far-eastern Nepal Himalaya. Tectonics 10, 851. doi:10.1029/91TC01011

Schelling, D., Cater, J., Seago, R., Ojha, T.P., 1991. A Balanced Cross-Section Across the Central Nepal Siwalik Hills; Hitauda to Amlekhgani. Department of Geology and Mineralogy Hokkaido University 23, I-9. 
Schulte-Pelkum, V., Monsalve, G., Sheehan, A., Pandey, M.R., Sapkota, S., Bilham, R., Wu, F., 2005. Imaging the Indian subcontinent beneath the Himalaya. Nature 435, $1222-$ 1225. doi:10.1038/nature03678.

Shresta, S., Shresta, J., Sharma, S., 1985. Geological map of Central Nepal at $1: 250000$ scale.

Schwartz, D.P., Coppersmith, K.J., Swan F.H., Somerville, P., Savage, W. U., 1981. Characteristic earthquakes on intraplate normal faults (abstract), Earthquakes Notes, 51, 71, 1981.

Schwartz, D.P., Coppersmith, K.J., 1984. Fault behavior and characteristic earthquakes: Examples from the Wasatch and San Andreas Fault Zones. Journal Geophysical Research 89, 5681. doi:10.1029/JB089iB07p05681

Seeber, L., Armbruster, J.G., 1981. Great detachment earthquakes along the Himalayan Arc and long-term forecasting, in: Earthquake Prediction: An international review, D.W. Sibson and P.G. Richards, E. (Ed.), American Geophysical Union. Maurice Ewing Series, 4, American Geophysical Union, pp. 259-277. doi:10.1029/ME004p0259

Sibson, R.H., 1983. Continental fault structure and the shallow earthquake source. Journal Geological Society of London. 140, 741-767. doi:10.1144/gsjgs.140.5.0741

Silver, C.R.P., Murphy, M.A., Taylor, M.H., Gosse, J., Baltz, T., 2015. Neotectonics of the Western Nepal Fault System: Implications for Himalayan strain-partitioning. Tectonics n/a-n/a. doi:10.1002/2014TC003730

Stocklin, J., 1980. Geology of Nepal and its regional frame. Journal Geological Society of London 137, 1-34.

Szeliga, W., Hough, S., Martin, S., Bilham, R., 2010. Intensity, magnitude, location, and attenuation in India for felt earthquakes since 1762. Bulletin Seismological Society of America 100, 570-584. doi:10.1785/0120080329

Takigami, Y., Sakai, H., Orihashi, Y., 2002. 1.5-1.7 Ga rocks discovered from the Lesser Himalaya and Siwalik belt: 40Ar-39Ar ages and their significances in the evolution of the Himalayan orogen. Geochemica Cosmochemica Acta 66.

Thapa, G.S., 1997. Microseismic epicenter map of Nepal Himalaya and adjoining region. Published by Department of Mines and Geology (Kathmandu, Nepal)

Ujiie, K., Kimura, G., 2014. Earthquake faulting in subduction zones: insights from fault rocks in accretionary prisms. Progress in Earth and Planetary Sciences 1, 7. doi:10.1186/2197-4284-1-7 
Upreti, B.N., 1999. An overview of the stratigraphy and tectonics of the Nepal Himalaya. Journal Asian Earth Science 17, 577-606. doi:10.1016/S1367-9120(99)00047-4

Verma, R.K., 1985. Gravity Field, Sismicity and Tectonics of the Indian Peninsula. Reidel Publishing Company. 209 p.

Wallace, K., Bilham, R., Blume, F., Gaur, V.K., Gahalaut, V., 2005. Surface deformation in the region of the 1905 Kangra $\mathrm{Mw}=7.8$ earthquake in the period 1846-2001. Geophys. Res. Lett. 32, L15307. doi:10.1029/2005GL022906.

Wobus, C.W., Whipple, K.X., Hodges, K.V., 2006. Neotectonics of the central Nepalese Himalaya: Constraints from geomorphology, detrital40Ar/39Ar thermochronology, and thermal modeling. Tectonics 25, 1-18. doi:10.1029/2005TC001935.

Yagi, Y., Okuwaki, R., 2015. Integrated seismic source model of the 2015 Gorkha, Nepal, earthquake. Geophysical Research Letters n/a-n/a. doi:10.1002/2015GL064995

Yule, D., Dawson, S., Lave, J., Sapkota, S., Tiwari, D., 2006. Possible evidence for surface rupture of the Main Frontal Thrust during the great 1505 Himalayan earthquake, Far-Western Nepal. EOS Trans. AGU )52 (Fall Meet. Suppl., Abstract S33C-05).

Zhang, G., Hetland, E., Shan, X., 2015. Slip in the 2015 Mw 7.9 Gorkha and Mw 7.3 Kodari, Nepal, earthquakes revealed by seismic and geodetic data: Delayed slip in the Gorkha and slip deficit between the two earthquakes. Seismological Research Letters 86, 1578-1586. doi:10.1785/0220150139

Zhao, W., Nelson, K.D., Che, J., Quo, J., Lu, D., Wu, C., Liu, X., 1993. Deep seismic reflection evidence for continental underthrusting beneath southern Tibet. Nature 366, 557559. doi:10.1038/366557a0 


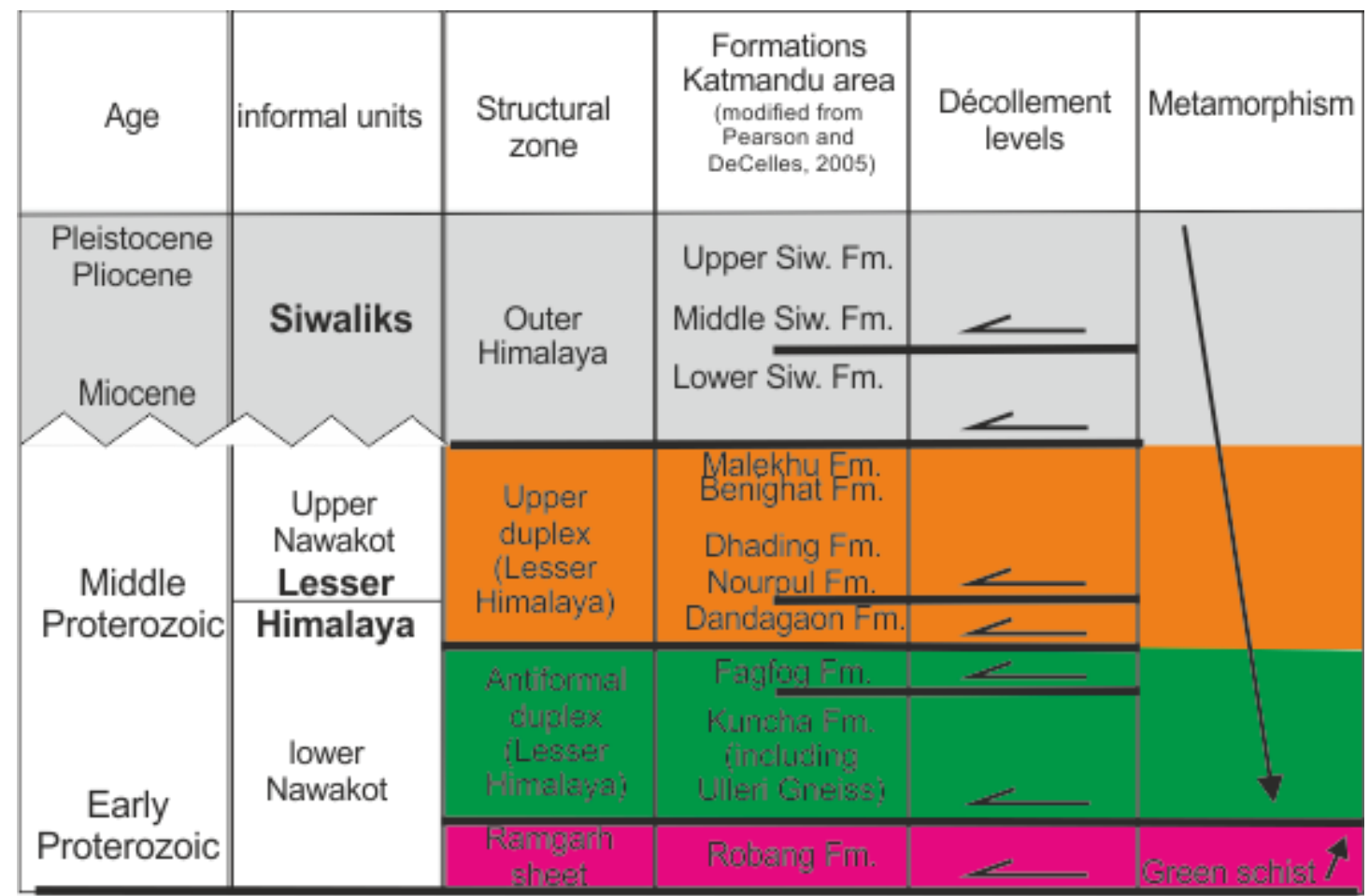

Table 1: Simplified stratigraphic column of the series in the Siwalik and Lesser Himalaya zones. The two columns on the right-hand side refer to the location of the main décollements (after Pearson and De Celles, 2005) and to the bulk evolution of the metamorphism.

\begin{tabular}{|c|c|c|c|c|}
\hline Id & $\mathrm{Mw}$ & Lat & Long & Date \\
\hline 1 & 5.7 & 27.73 & 86.11 & $24 / 03 / 1974$ \\
\hline 2 & 6.6 & 27.18 & 86.61 & $20 / 08 / 1988$ \\
\hline 3 & 4.7 & 28.38 & 84.88 & $31 / 10 / 2005$ \\
\hline 4 & 5 & 27.46 & 86.56 & $18 / 12 / 2014$ \\
\hline 5 & 7.9 & 27.91 & 85.33 & $25 / 04 / 2015$ \\
\hline 6 & 6.7 & 27.86 & 84.93 & $25 / 04 / 2015$ \\
\hline 7 & 5.3 & 28.06 & 85.89 & $25 / 04 / 2015$ \\
\hline 8 & 5.1 & 27.61 & 84.96 & $25 / 04 / 2015$ \\
\hline 9 & 6.7 & 27.56 & 85.95 & $26 / 04 / 2015$ \\
\hline 10 & 5.2 & 27.56 & 85.9 & $26 / 04 / 2015$ \\
\hline 11 & 7.2 & 27.67 & 86.08 & $12 / 05 / 2015$ \\
\hline 12 & 6.1 & 27.37 & 86.35 & $12 / 05 / 2015$ \\
\hline 13 & 5.3 & 27.37 & 86.26 & $16 / 05 / 2015$ \\
\hline
\end{tabular}

1140 Table 2: Characteristics of the focal mechanisms plotted in Figure 6 (From Global CMT

1141 Catalog). The "Id" column refers to the identification numbers in Figure 6. 


\section{FIGURE CAPTIONS}

Fig. 1: Location of the rupture of the April 2015 earthquake (after Grandin et al., 2015), other historic Himalayan earthquakes and the main Himalayan tectonic structures. MFT, MBT and MCT stand for Main Frontal Thrust, Main Boundary Thrust and Main Central Thrust, respectively. Kat. stands for Kathmandu and Na. for Narayani dun. 1934 epicentre after Chen and Molnar (1977), 1866 epicentre after Szeliga et al. (2010), 1833 epicentre after Mugnier et al. (2013), and 1505 epicentre after Ambraseys and Douglas (2004). The MKS isoseismal contour intensity = VII modified from Ambraseys and Douglas (2004) for the 1934 and 1833 events and inferred for the 1505 event following Ambraseys and Jackson (2003). The lineaments and active faults transverse to the Himalayan belt follow Mugnier et al. (1999), Kayal (2008) and Silver et al. (2015) (GL: Gaurishankar lineament; JL: Judi lineament; BGF: Bhari Gad Fault; TG: Takhola graben; KF: Karakoram Fault).

Fig. 2: Geology of the Kathmandu area.

(A) The geological map was adapted from Stocklin (1980), Shresta et al. (1985), Rai (1998) and Pearson and De Celles, (2005). See Table 1 for the meaning of the light grey, orange green and purple colours; the red and blue colours refer to the High Himalaya and to the Tethyan Himalaya, respectively. Dashed black lines refer to the lineament of the Judi and Gaurishankar lineaments (Kayal, 2008), dots refer to pierce points of the branching line at the edge of the upper duplex. Same meaning as figure one for the initials, except for the following: LD1 to LD3 are horses made of the Lower Nawakot series; MF and JF are active faults, the Mahabharat fault and Jhiku Khola fault respectively.

(B) Branch-line map of the Upper Nawakot duplex. The coloured areas refer to the extent of the Upper Nawakot duplex. The dark colour indicates the buried duplex; an intermediate colour was used for the partly eroded duplex (i.e. present-day outcrops); and the light colour signifies the fully eroded duplex. A dotted line was used to delineate the branch line between the floor thrust and Ramgarh Thrust (RT) at the trailing edge of the Upper Nawakot duplex; a dashed line was used for the branch line between the MBT and RT at the leading edge of the Upper Nawakot duplex. 
(C) Branch-line map of the antiformal duplex. The coloured areas refer to the extent of the antiformal duplex. Dark colour: buried duplex; light colour: partly eroded duplex. The thick dotted-dashed line refers to the footwall cut-off of the lower Nawakot series, i.e. the ramp/flat transition at the crustal scale.

Fig. 3: Balanced cross-section at the crustal scale illustrating the relationships between the different structural units (see location in Figure 3) restored at $0 \mathrm{Ma}(\mathrm{A}), \sim 5-8 \mathrm{Ma}(\mathrm{B})$ and $\sim 10-15 \mathrm{Ma}(\mathrm{C})$, respectively. The dots $P$ and $L$ represent the present-day Palung granite and Langtang outcrops, respectively. The pine line for the restoration is located in the hanging wall in order to outline the underthrusting component.

Fig. 4: Structures of the frontal Siwalik belt. See Fig. 2 for location. (A) Cross-section close to the Indian border at the lateral tip of the MFT (from Leturmy, 1997); (B) cross-section along the Bagmati River (adapted from Delcaillau, 1986; Lavé and Avouac, 2000 and Dhital, 2015). MFT, MDT, ID MBT, RT MCT refer to the Main Frontal Thrust, Main Dun Thrust, Internal (Siwalik) Décollement, Main Boundary Thrust, Ramgarh Thrust and Main Central Thrust, respectively.

Fig. 5: The 2015 rupture compared to the main geological features. Same caption for the geology as in Fig. 2A. The black and white dashed line indicates the ramp-flat transition inferred from micro-seismicity (Fig. 8). (A) Rupture of the 25 April earthquake. The grey areas show the zone with significant slip (>2, > 4 and $>6 \mathrm{~m}$, respectively) of the 25 April 2015 Gorkha earthquake and the 12 May 2015 earthquake (from Grandin et al., 2015). The black star represents the epicentre of the main earthquakes (2015 events from GCMT; 1866 from Szeliga et al., 2010; 1833 from Mugnier et al., 2011). (B) The three stages of the rupture propagation inferred from the back projection of teleseismic P waves (from Fan and Shearer, 2015). Each ellipse represents the low-frequency power images integrated in a $5 \mathrm{~s}$ window and normalized with the maximum power of each $5 s$ window. Green set of ellipses for the first 20 seconds, brown set between 20 to $40 \mathrm{~s}$ and blue set between 40 to $50 \mathrm{~s}$. Each numbered white arrow represents a stage of the rupture through the successive power images. 
1203

1204

1205

1206

1207

1208

1209

1210

1211

1212

1213

1214

1215

1216

1217

1218

1219

1220

1221

1222

1223

1224

1225

1226

1227

1228

1229

1230

Fig. 6: The 2015 aftershock sequence (from Adhikari et al., 2015) compared with the main geologic features. The colour and size of the circles refers to the date and magnitude of the events, respectively. The colours of the focal mechanisms of the earthquakes (numbered in Table 2) are black for the period before the 25 April 2015 earthquake, blue for the events after the 25 April event and red for the events after 12 May 2015. The oblique dashed lines refer to the Judi and Gaurishankar lineaments (Kayal, 2008) and the reast-west dashed line to the ramp-flat transition along the MHT (see text for discussion).

Fig. 7: Crustal cross-section through the 2015 earthquake rupture and parallel to the slip direction (location in Fig. 1). Sub-Himalayan belt adapted from Schelling et al. (1991) and Leturmy (1997); MHT dip and depth from the rupture of the 2015 earthquake (GCMT, NEIC, and Fan and Shearer, 2015); lower antiformal duplex (made up of the Lower Nawakot series) adapted from Shresta et al. (1985) and Pearson and De Celles (2005), (LD1 to LD5 for the five horses). Upper Nawakot duplex from Pearson and De Celles (2005) on the southern flank of the Kathmandu nappe, and inferred from Shresta et al. (1985) beneath the Kathmandu nappe. More than $80 \%$ of the interseismic events relocated by Rajaure et al. (2013) fall within the narrow yellow zone.

Fig. 8: Three possible origins for the locations of the edges of the ruptures in the Himalaya: 1) ramp hanging wall cut-offs or the branching of transported faults induce variations in the lithology and possibly in fluid pressures; 2) footwall cut-offs induce geometric singularities along the trajectory of the active fault; 3) a brittle/ductile transition is induced by the thermal conditions.

Fig. 9: A sketch of the possible relationships between pre-existing structures (strike-slip fault in the basement or lateral sedimentary variations) and transverse structures. Right side crosssections are located on the block-diagrams shown on the left side. The circles outline the zones that could be the lateral edges of seismic ruptures. A) lateral ramp of the thrust system 
with no pre-existing fault in the basement; A) major reactivation of the pre-existing strike-slip as a wrench fault in the basement that also offset the hanging wall structures; $C)$ weak vertical reactivation of the pre-existing fault inducing a transverse warping of the basal décollement and of the hanging wall structures; D) localization of a lateral ramp induced by lateral sedimentary variations.

Fig. 10: A possible spatio-temporel distribution of the Himalayan ruptures based on the multiple patch model for the MHT in central and eastern Nepal. A) Topography and physiology of the surface (from Google earth pro assemblage); MFT, GL, JL, TG, KTM are Main Frontal Thrust, Gaurishankar lineament, Judi lineament, Takhola graben and Kathmandu respectively. B) Distribution of the ruptures along the britle part of the MHT. (Rose for purely brittle, light purple for brittle/ductile transition zone, light blue for the ramp). The epicentres (red stars) and rupture extent (red patch) of the great historical earthquakes and frontal rupture have been adapted from Ambraseys and Jackson (2003), Bilham (1995), Szeliga et al. (2010), Mugnier et al. (2011), Bollinger et al. (2013), Grandin et al. (2015) and (Chamlagain et al., 2016). C) Simplified bloc diagram of MHT with inferred rheology (Brittle/transition zone in light purple inferred from a coupling ratio between 20 and $80 \%$ ) adapted from Jouanne et al. (2016). 


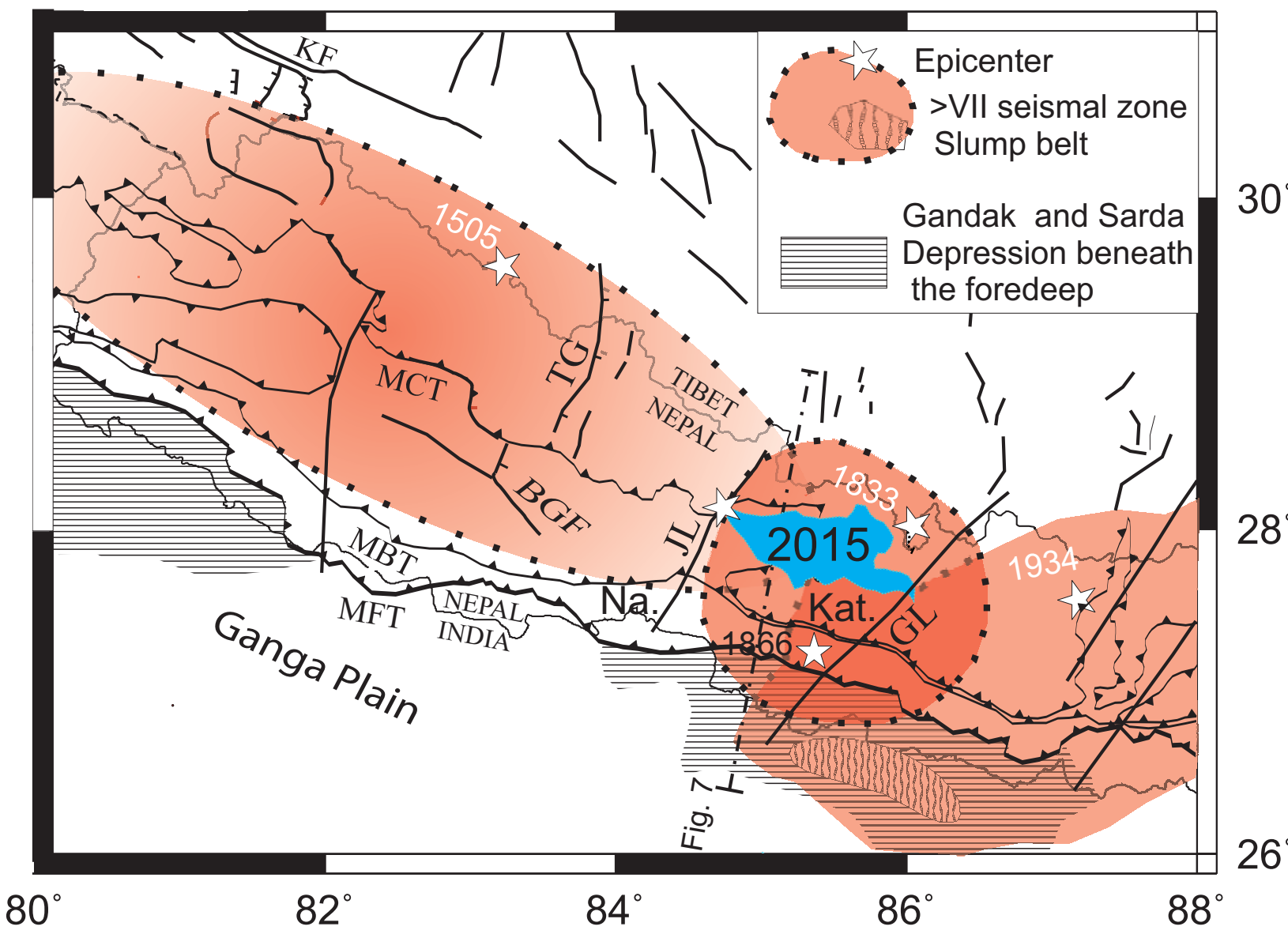


Fig. 2

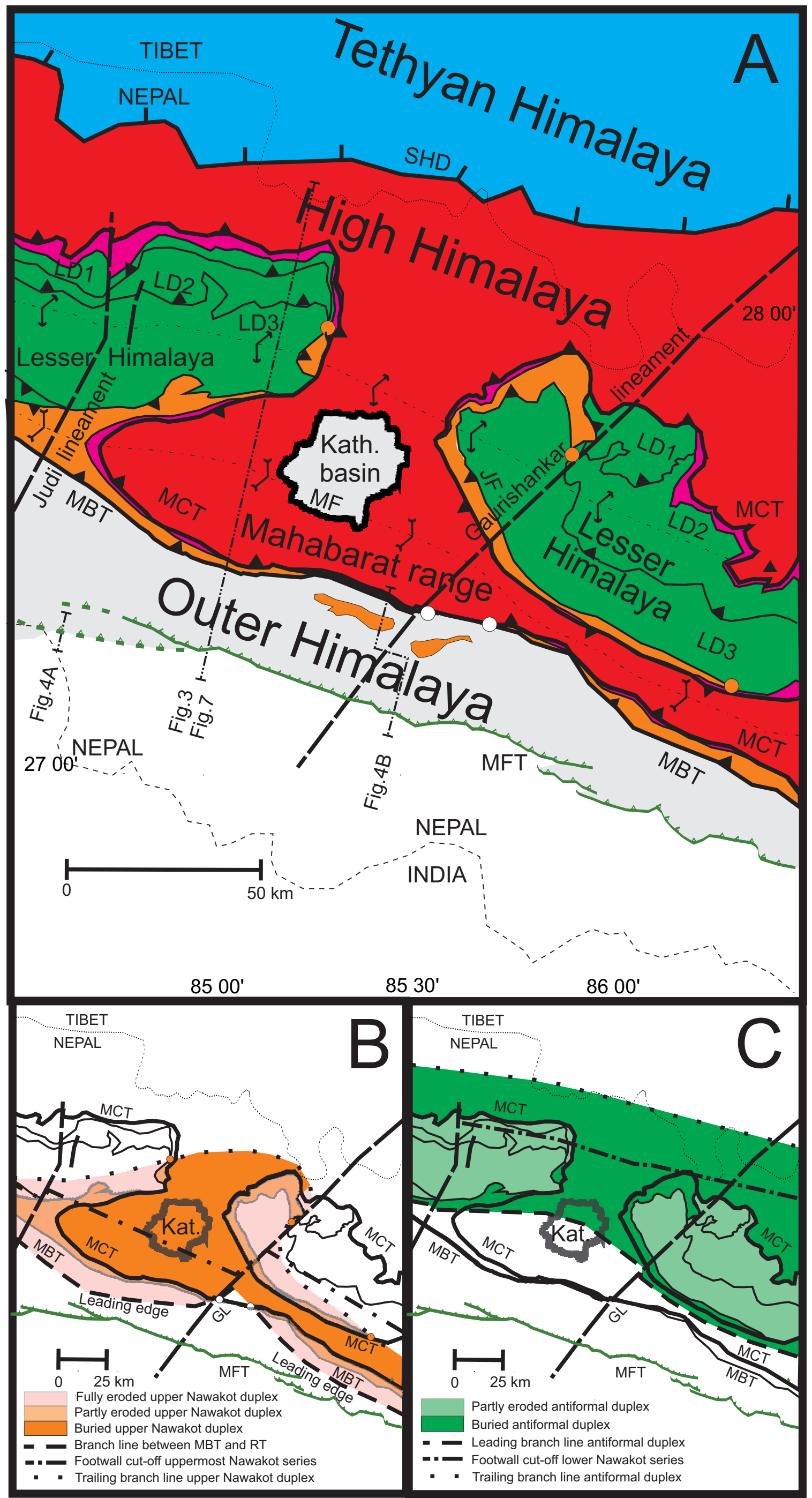




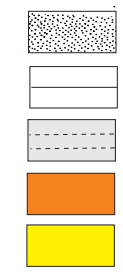

Upper Siwaliks

Middle Siwaliks

Lower Siwaliks

Upper Nawakot units

Fully eroded Lesser Himalaya

$P_{\bullet}$ Palung granite

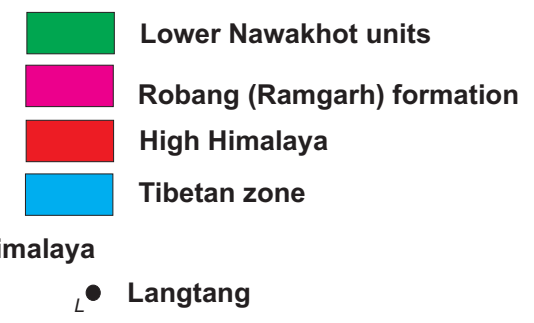

Robang (Ramgarh) formation

High Himalaya

- Langtang

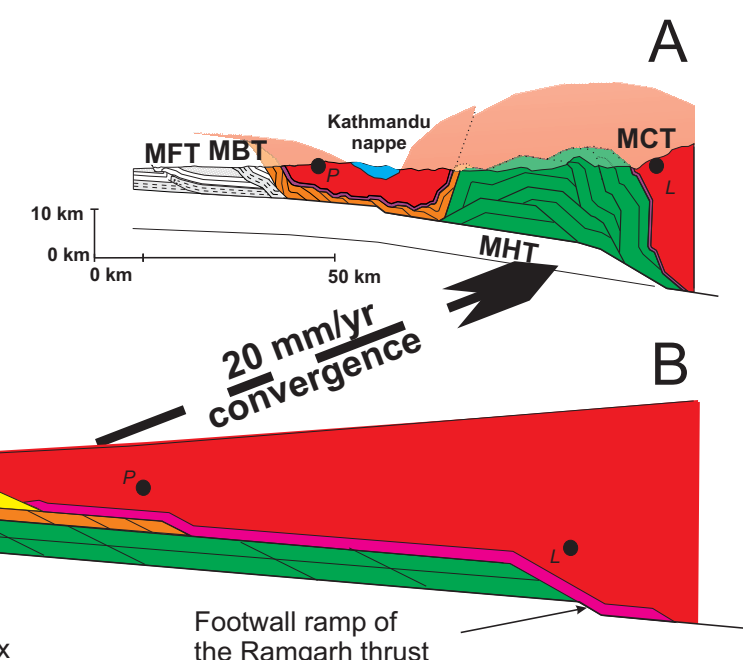

the Ramgarh thrust

C
Footwall ramp of

the lower Nawakot duplex

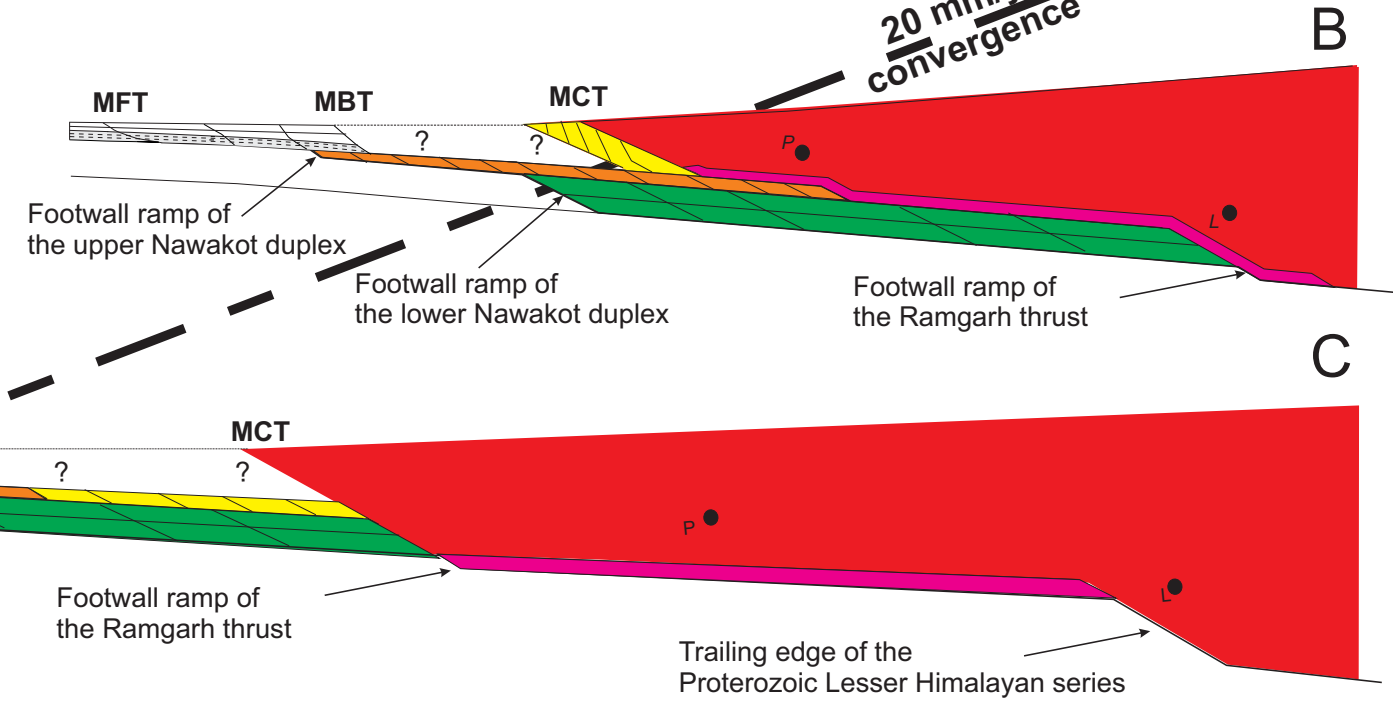


Fig. 4

A

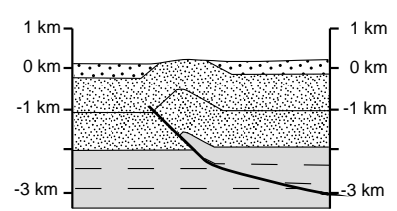

B

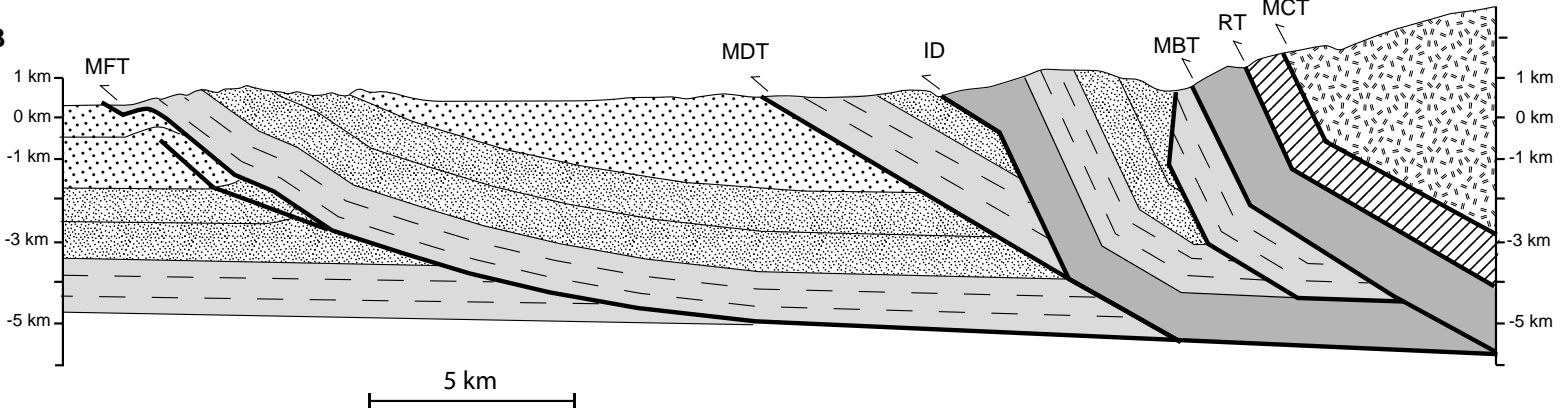

Upper Siwalik

Middle Siwalik

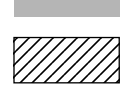

Lesser Himalaya Dandagaon formation

$\checkmark \checkmark$

Middle Siwalk

and

Lesser Himalaya Robang formation

- - - Lower Siwalik

High Himalaya 

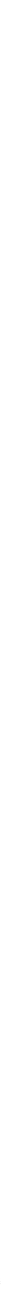

Fig. 5 


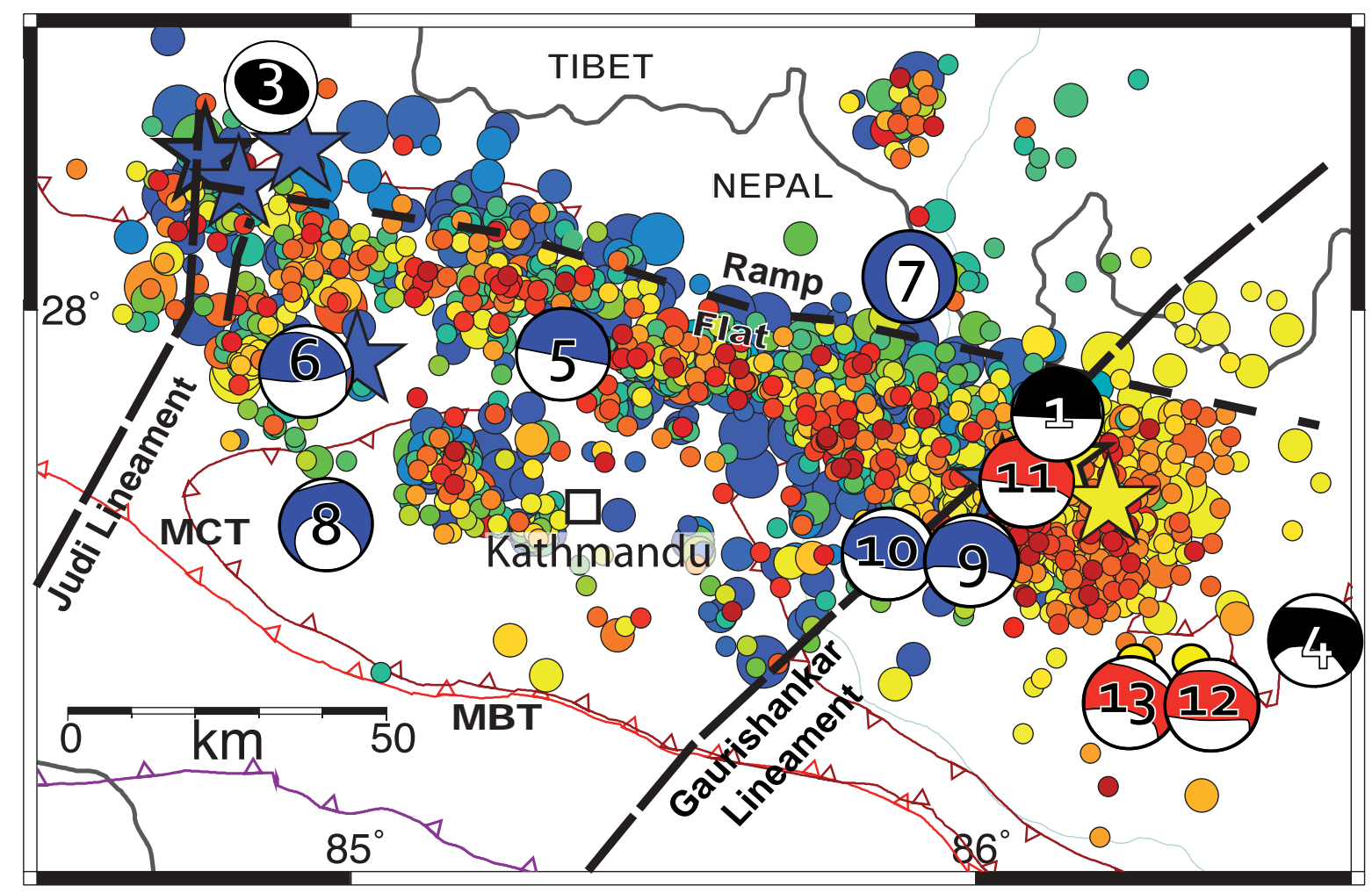

\begin{tabular}{|l|}
\hline Magnitude scale \\
\hline $\begin{array}{l}\mathrm{ML}>=6.0 \\
5.0=<\mathrm{ML}<6.0 \\
4.0=<\mathrm{ML}<5.0 \\
3.0=<\mathrm{ML}<4.0\end{array}$ \\
\hline Time scale \\
\hline May 30 \\
May 12 \\
\hline
\end{tabular}


1- variation of lithology 2- geometric singularity

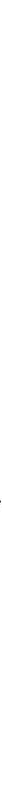

3- brittle/ductile transition

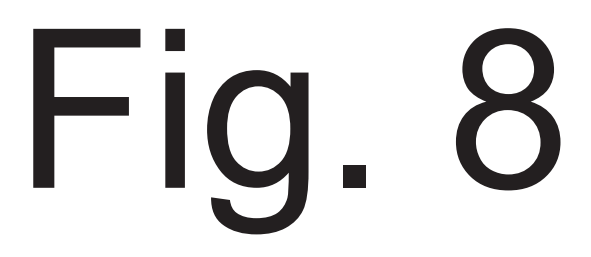




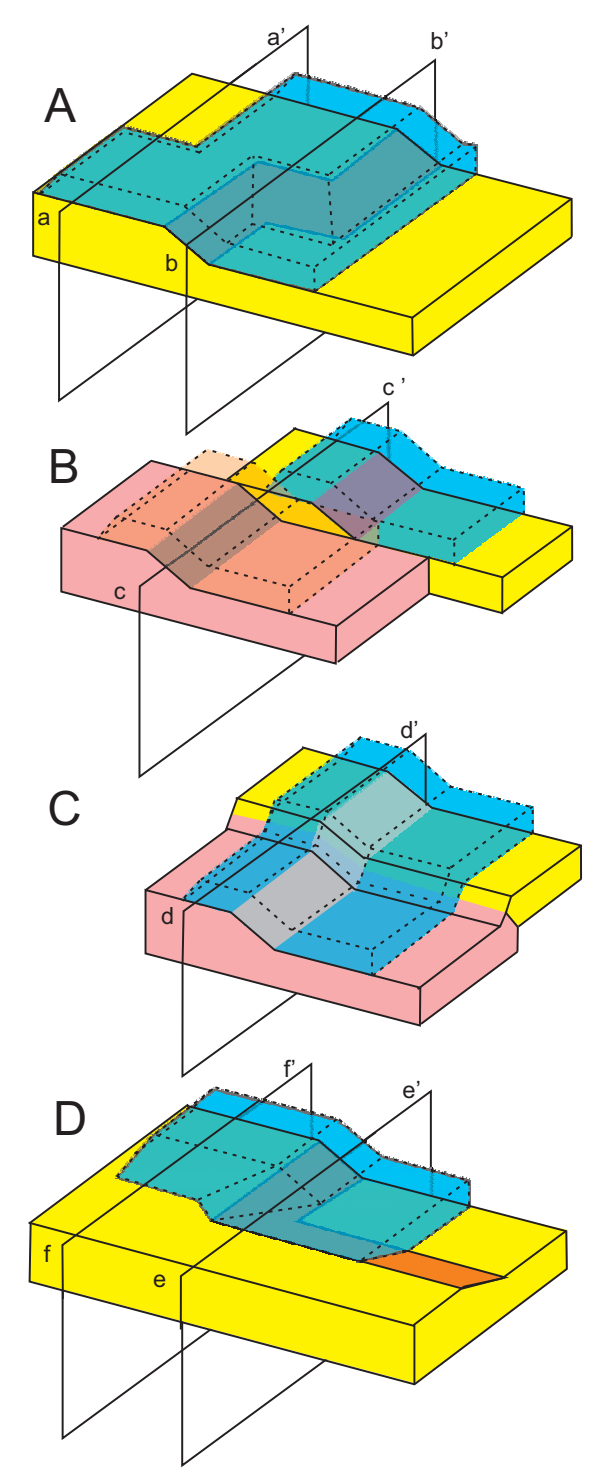

a

a'
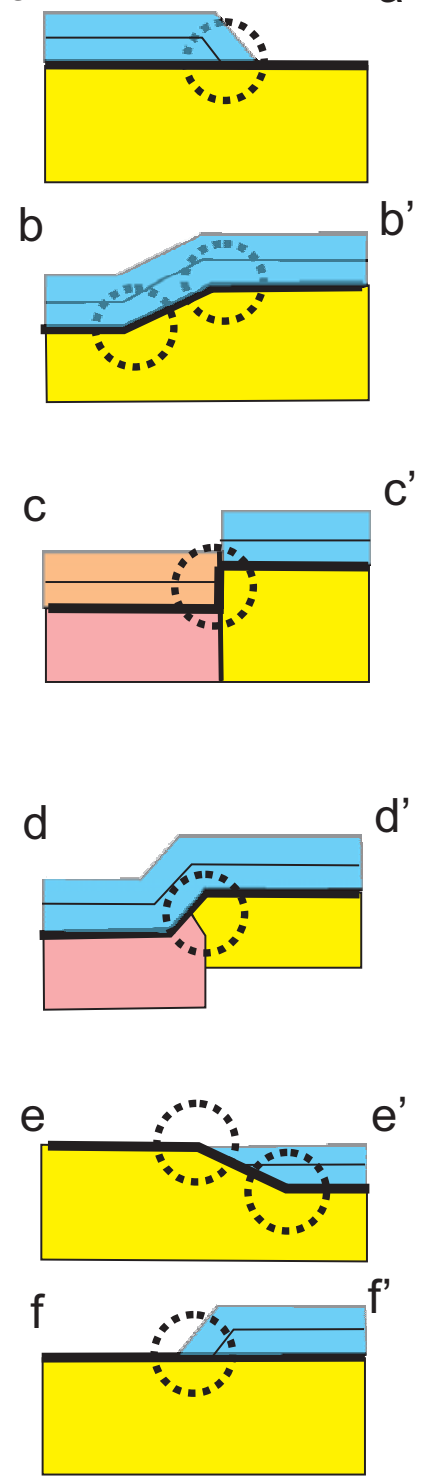

Figureg 


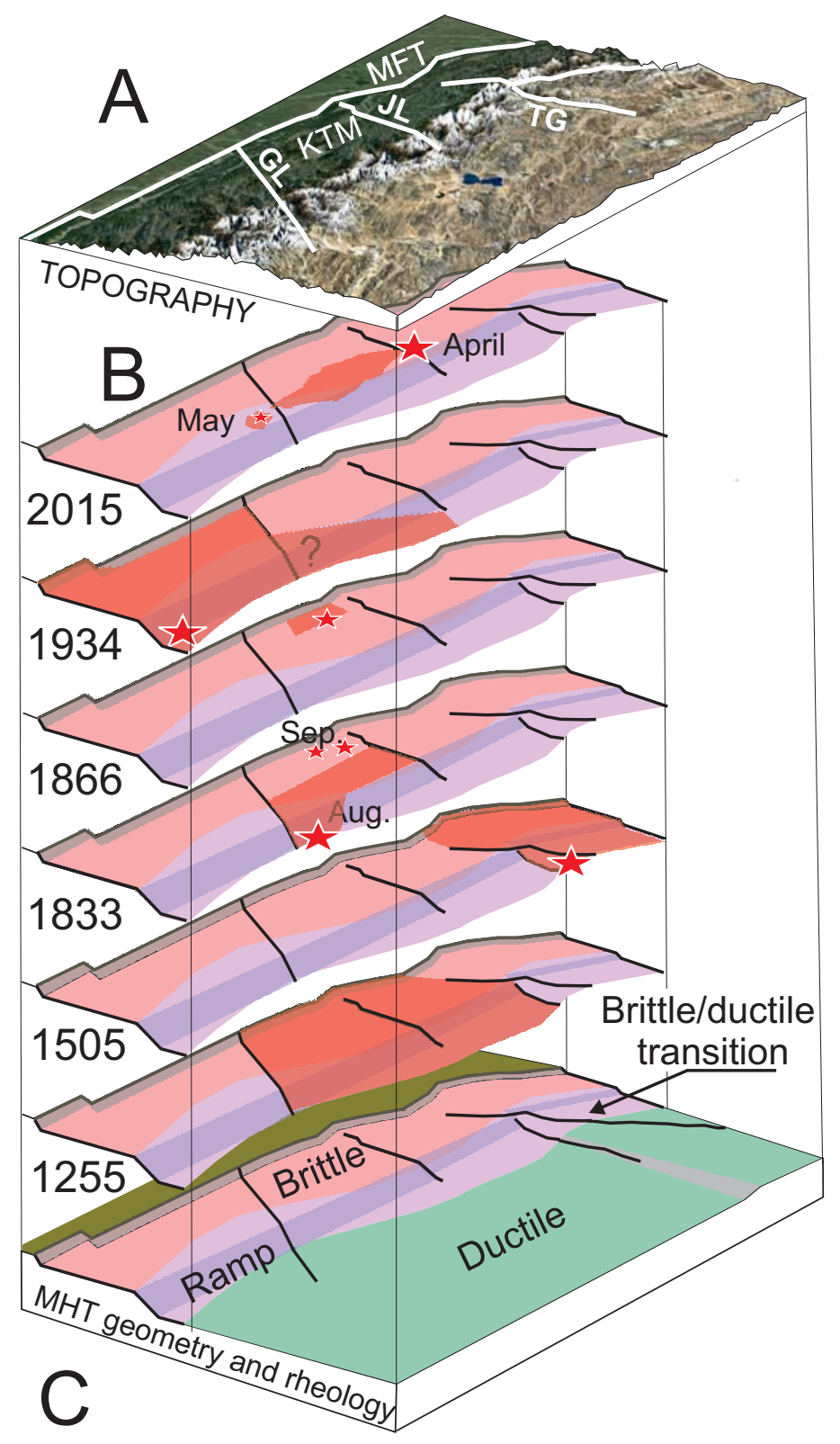




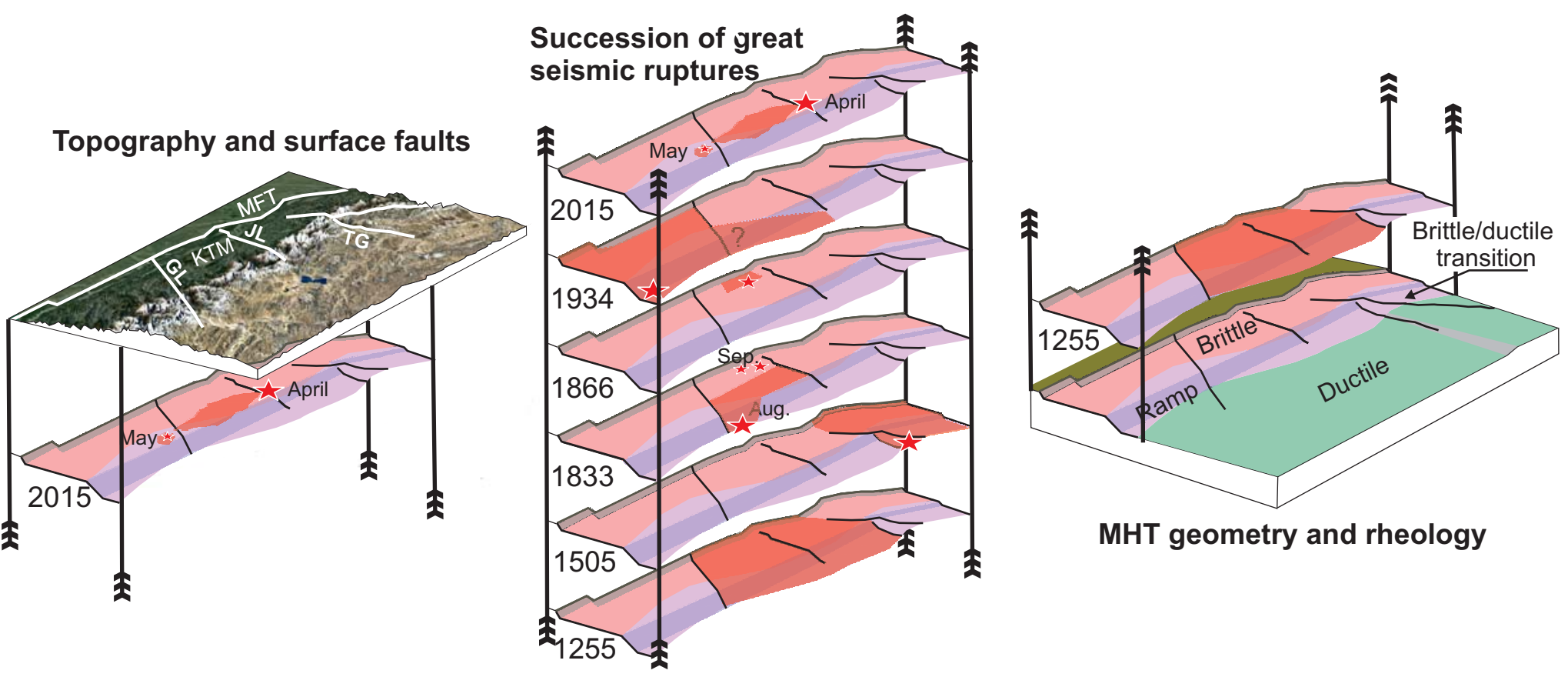




\begin{tabular}{|c|c|c|c|c|c|}
\hline Age & informal units & $\begin{array}{l}\text { Structural } \\
\text { zone }\end{array}$ & $\begin{array}{l}\text { Formations } \\
\text { Katmandu area } \\
\text { (modified from } \\
\text { Pearson and } \\
\text { DeCelles, 2005) }\end{array}$ & $\begin{array}{c}\text { Décollement } \\
\text { levels }\end{array}$ & Metamorphism \\
\hline $\begin{array}{l}\text { Pleistocene } \\
\text { Pliocene }\end{array}$ & \multirow[t]{2}{*}{ Siwaliks } & \multirow{2}{*}{$\begin{array}{l}\text { Outer } \\
\text { Himalaya }\end{array}$} & $\begin{array}{l}\text { Upper Siw. Fm. } \\
\text { Middle Siw. Fm. }\end{array}$ & $<$ & \\
\hline Miocene & & & Lower Siw. Fm. & $<$ & \\
\hline \multirow[t]{2}{*}{$\begin{array}{c}\text { Middle } \\
\text { Proterozoic }\end{array}$} & $\begin{array}{c}\text { Upper } \\
\text { Nawakot } \\
\text { Lesser } \\
\text { Himalaya }\end{array}$ & $\begin{array}{l}\text { Upper } \\
\text { duplex } \\
\text { (Lesser } \\
\text { Himalaya) }\end{array}$ & $\begin{array}{l}\text { Malekhu Fm. } \\
\text { Benighat Fm. } \\
\text { Dhading Fm. } \\
\text { Nourpul Fm. } \\
\text { Dandagaon Fm. }\end{array}$ & $<$ & \\
\hline & Himalaya & $\begin{array}{l}\text { Antiformal } \\
\text { duplex } \\
\text { (Lesser } \\
\text { Himalaya) }\end{array}$ & $\begin{array}{l}\text { Fagfog Fm. } \\
\text { Kuncha Fm. } \\
\text { (including } \\
\text { Ulleri Gneiss) }\end{array}$ & $<$ & \\
\hline Proterozoic & & $\begin{array}{l}\text { Ramgarh } \\
\text { sheet }\end{array}$ & Robang Fm. & $<$ & Green schist 1 \\
\hline
\end{tabular}




\begin{tabular}{|c|c|c|c|c|}
\hline $\mathrm{Id}$ & $\mathrm{Mw}$ & Lat & Long & Date \\
\hline 1 & 5.7 & 27.73 & 86.11 & $24 / 03 / 1974$ \\
\hline 2 & 6.6 & 27.18 & 86.61 & $20 / 08 / 1988$ \\
\hline 3 & 4.7 & 28.38 & 84.88 & $31 / 10 / 2005$ \\
\hline 4 & 5 & 27.46 & 86.56 & $18 / 12 / 2014$ \\
\hline 5 & 7.9 & 27.91 & 85.33 & $25 / 04 / 2015$ \\
\hline 6 & 6.7 & 27.86 & 84.93 & $25 / 04 / 2015$ \\
\hline 7 & 5.3 & 28.06 & 85.89 & $25 / 04 / 2015$ \\
\hline 8 & 5.1 & 27.61 & 84.96 & $25 / 04 / 2015$ \\
\hline 9 & 6.7 & 27.56 & 85.95 & $26 / 04 / 2015$ \\
\hline 10 & 5.2 & 27.56 & 85.9 & $26 / 04 / 2015$ \\
\hline 11 & 7.2 & 27.67 & 86.08 & $12 / 05 / 2015$ \\
\hline 12 & 6.1 & 27.37 & 86.35 & $12 / 05 / 2015$ \\
\hline 13 & 5.3 & 27.37 & 86.26 & $16 / 05 / 2015$ \\
\hline
\end{tabular}

